\title{
AS ESTÁTUAS DO "MERCÚRIO VOADOR" EM PELOTAS E NO BRASIL1.
}

Fábio Vergara Cerqueira²

Isabel Halfen da Costa Torino ${ }^{3}$

\begin{abstract}
Resumo
Este artigo tem como tema central um símbolo do patrimônio cultural pelotense que esteve desaparecido por longo tempo, embora tenha permanecido no imaginário pelotense, tendo sido objeto de reivindicações patrimoniais por alguns setores da sociedade: trata-se da escultura em metal que do deus greco-romano Hermes/Mercúrio. Esteve fixada no alto da torre do Mercado Central de Pelotas desde aproximadamente 1914, vindo a desaparecer entre a década de 1950 e 1960 e reaparecendo há poucos anos. O texto, ao apreciar o contexto cultural da chegada do Mercúrio em Pelotas, aborda-o como um fenômeno de Recepção da Antiguidade, ligado à formação de uma identidade urbana e a uma ideia de civilização; considera-o como produto de uma apropriação moderna, ocorrida não somente em escala local, mas também global, e que pode ser percebida em algumas cidades brasileiras que tiveram momento de prosperidade econômico-cultural coevo e análogo ao de Pelotas.
\end{abstract}

\section{Palavras-chave}

Escultura; Mercúrio; identidade urbana; Pelotas.

\footnotetext{
1 Versão revisada do artigo "Der Merkur von Pelotas und die Merkurstatuen in Brasilien", publicado anteriormente em Thetis. Mannheimer Beiträge zur Archäologie und Geschichte der Antiken Mittelmeerkulturen. 23, 2016-2018, p. 85-92, pr. XXXVIII-XLV. Agradecemos ao editor, Prof. Dr. Reinhard Stupperich, a autorização para publicar a tradução revisada do texto.

2 Professor Titular, Universidade Federal de Pelotas.

${ }^{3}$ Doutoranda, Universidade Federal de Pelotas.
}

Heródoto, Unifesp, Guarulhos, v. 4, n. 2, 2019.2 p. 206-240

DOI: $10.34024 /$ herodoto.2019.v4.10973 


\begin{abstract}
This article has as its central theme a symbol of the cultural heritage of Pelotas, which had been out of sight for a long time. And even while gone missing, it was present in the imagery of the city and was the object of heritage claims by some sectors of society. It is the metal sculpture which represents the Greco-Roman god Hermes/Mercury. It was fixed at the top of the tower of the Central Market probably in 1914, disappearing between the decades of 1950 and 1960 and reappearing a few years ago. The text, as it appreciates the context of the arrival of Mercury in Pelotas, approaches this fact as a phenomenon of Reception of Antiquity, connected to a process of construction of an urban identity, an idea of civilization. The text considers the statue as a product of a modern appropriation that occurred not only at a geographical scale, but also at a global one. This appropriation can be seen in some Brazilian cities that lived an analogous moment of economical and cultural prosperity like the one experienced by Pelotas.
\end{abstract}

\title{
Keywords
}

Sculpture; Mercury; Urban identity; Pelotas. 


\section{O Mercúrio de Pelotas}

O tema central desse artigo é uma escultura, em suporte de metal, do deus Hermes/Mercúrio. A estátua foi colocada na torre do Mercado Central de Pelotas após a grande reforma ${ }^{4}$ feita entre 1911 a 1914, acompanhando a tendência da virada de século, de usar o ferro na construção de prédios públicos, material que se difundia cada vez mais por todo o mundo. $\mathrm{Na}$ ocasião, acrescentaram-se ao antigo prédio quatro torreões adornados, um pavilhão e uma torre metálica de mais de $37 \mathrm{~m}$ de altura. A torre foi fabricada em Lüneburg, no Norte da Alemanha, e exportada em 1912 para o Brasil pelo porto de Hamburgo. A escultura, colocada no alto dessa torre, aludia ao comércio, pelos valores atribuídos a Mercúrio (Figura 1).

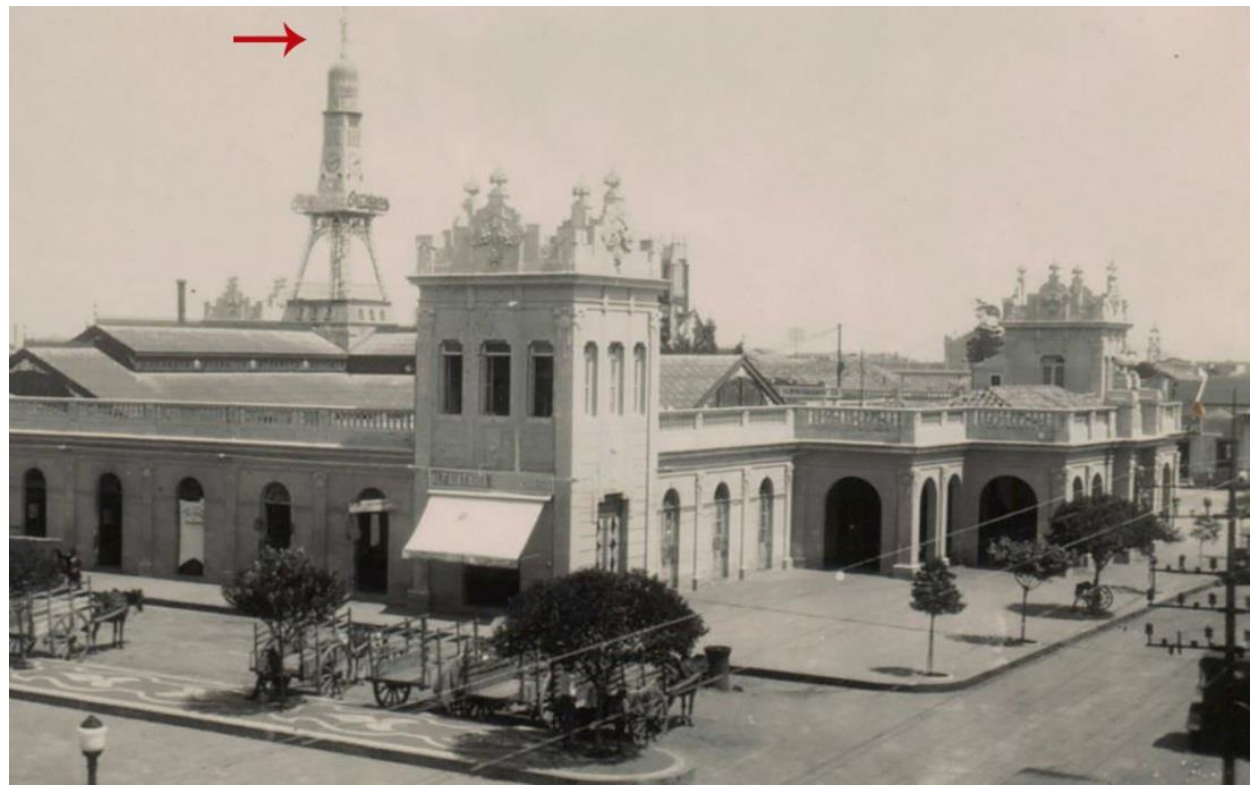

Figura 1: Fotografia do Mercado Central de Pelotas (aproximadamente 1920). Fonte: Acervo Nelson Nobre. Laboratório de Acervo Digital UCPel.

O Mercúrio foi instalado na torre por volta de 1914 e desapareceu entre os anos 50 e 60. Evidências visuais de meados do século passado mostram a presença da estátua ainda na torre, como revela a pintura do Mercado Público de Pelotas de 1948, de Francisco de Paula Faria Rosa Sobrinho (Figuras 2 e 3)5, e o desenho feito por Roberto Bonini, seu sobrinho-neto (Figura 4$)^{6}$. Mas quando ocorreu esse desaparecimento? Alguns relatam

\footnotetext{
4 O prédio do Mercado Central de Pelotas foi construído entre 1849 e 1856 (BRUNO 2010:22).

5 Pintura. Título: Mercado Público de Pelotas, 1948. Pintor: Francisco de Paula Faria Rosa Sobrinho. Mercado Público de Pelotas - óleo sobre tela, 33 X $45 \mathrm{~cm}$. O pintor mostra uma vista da torre do Mercado Central de Pelotas, sobre os telhados.

${ }^{6} \mathrm{O}$ desenho a lápis crayon preto e branco, por Roberto Moura Bonini, sobrinho-neto do pintor Francisco de Paula Faria Rosa Sobrinho, mostra a localização hipotética da estátua
} 
que a estátua foi derrubada por um temporal seguido de ventos fortes que assolou a cidade na década de 1950; outros acreditam que isso ocorreu no incêndio de 1969. No entanto, fotografias de meados dos anos 60 não mostram mais o Mercúrio na torre - em seu lugar, a torre exibe um letreiro da Pepsi. Assim, por mais de trinta anos, não se soube exatamente as circunstâncias do desaparecimento da escultura, nem tampouco seu paradeiro até aparecer novamente, após algumas décadas, parcialmente destruída (Figura 5).

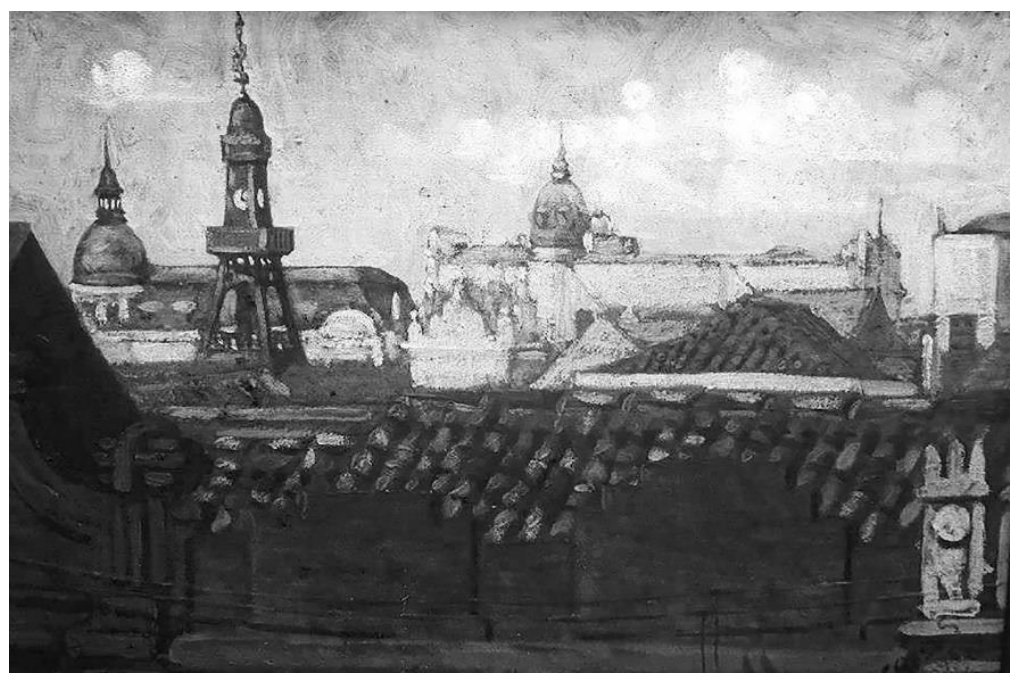

Figura 2: Pintura a óleo sobre tela, 33 X $45 \mathrm{~cm}$. Fonte: Acervo Roberto Moura Bonini.

de Mercúrio na torre do Mercado Central entre 1915 e 1960, com base em estudo feito por este comparando várias pinturas, fotografias e análises do ângulo e das proporções. 


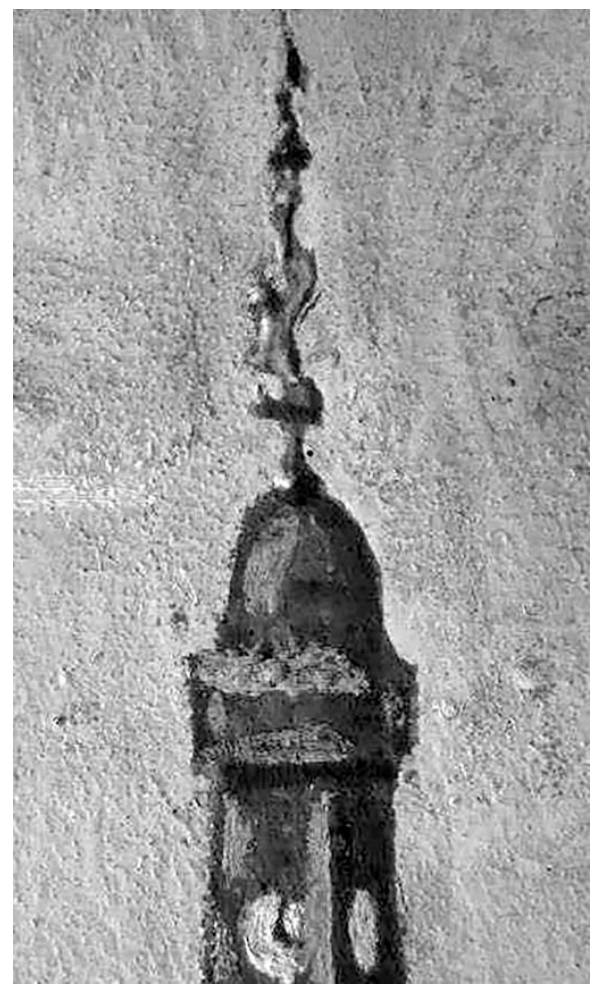

Figura 3: Pintura a óleo sobre tela, 33 X $45 \mathrm{~cm}$ (detalhe). Fonte: Acervo Roberto Moura Bonini.

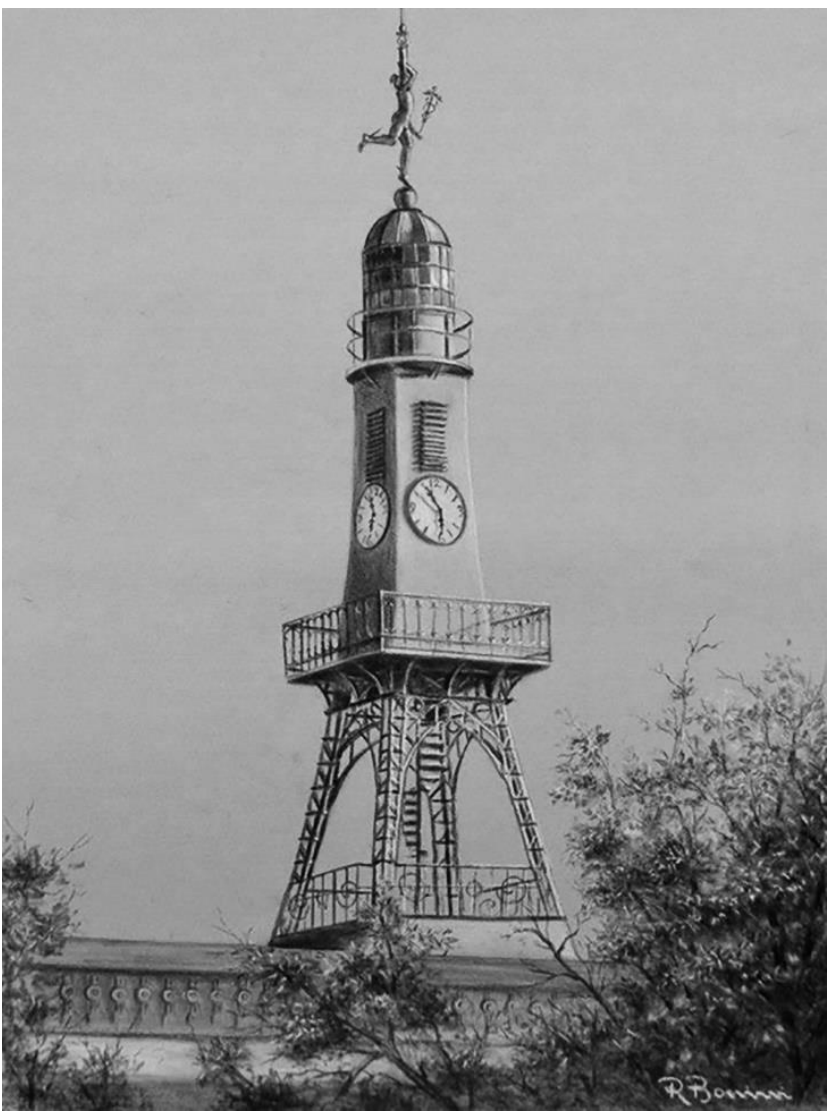

Figura 4: Desenho a lápis crayon preto e branco, $50 \times 70 \mathrm{~cm}$. Fonte: Acervo Roberto Moura Bonini.

Heródoto, Unifesp, Guarulhos, v. 4, n. 2, 2019.2 p. 206-240

DOI: 10.34024/herodoto.2019.v4.10973 

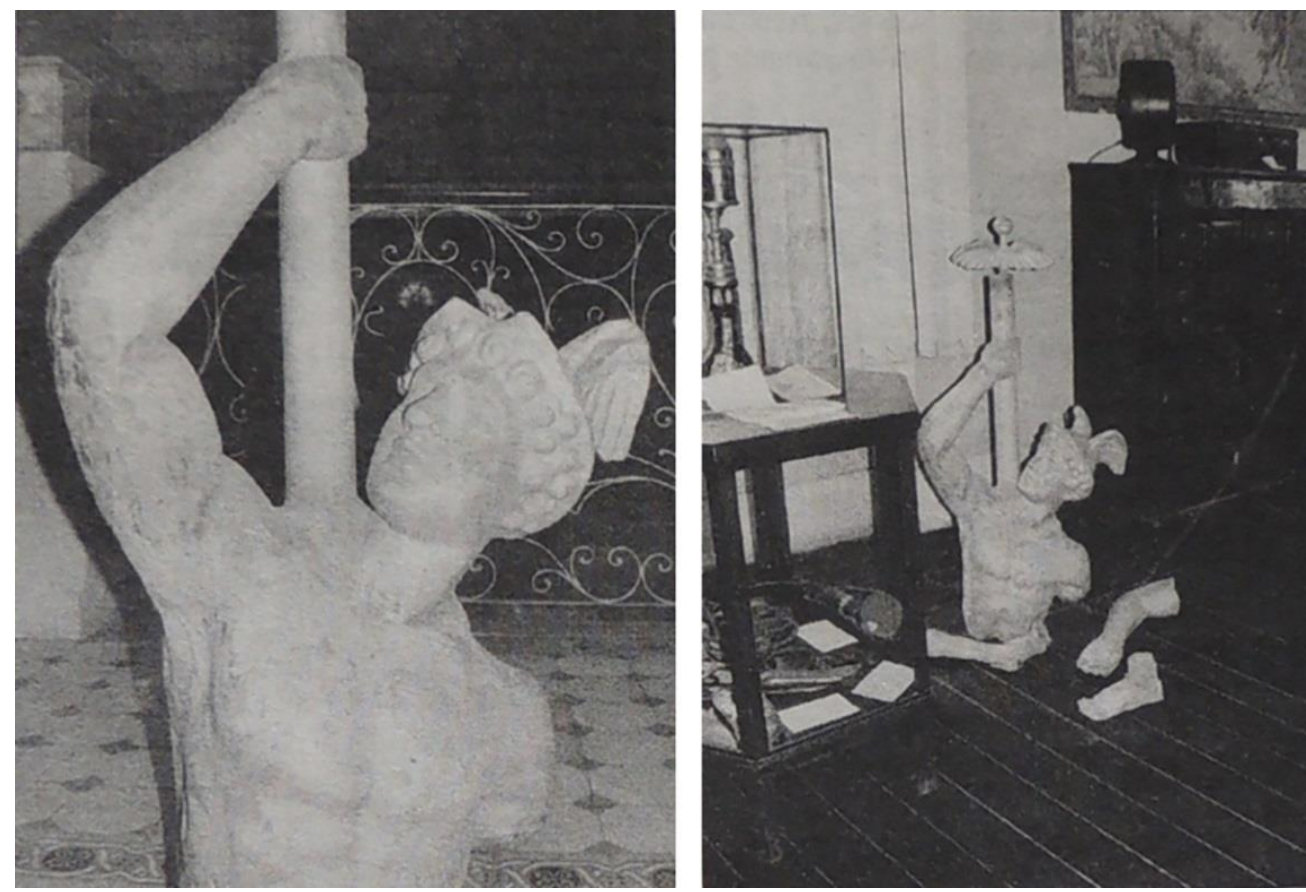

Figura 5: Escultura aos pedaços, no Museu da Bibliotheca Pública Pelotense. Fonte: Acervo Bibliotheca Pública Pelotense.

Medindo pouco mais de dois metros de altura, o Mercúrio de Pelotas (Figura 6$)^{7}$ reproduz o modelo da célebre obra do escultor maneirista Giambologna (1529-1608), atualmente exposta no Museu Nacional de Bargello, em Florença, na Itália (Figura 7). Trata-se de uma estátua que foi multiplicada, havendo inúmeras reproduções, em tamanhos variados, em várias partes do mundo. A representação segue a iconografia tradicional, com capacete alado (petasus alatus) e sandálias também aladas (endromides), segurando no braço esquerdo um caduceu (kerykeion). Recebe com frequência a denominação "Mercúrio voador".

\footnotetext{
7 Esta fotografia, no prédio da Secretaria Municipal de Cultura de Pelotas, em 2013, mostra o estado da escultura do deus Mercúrio após ter passado por duas intervenções de restauração.
} 


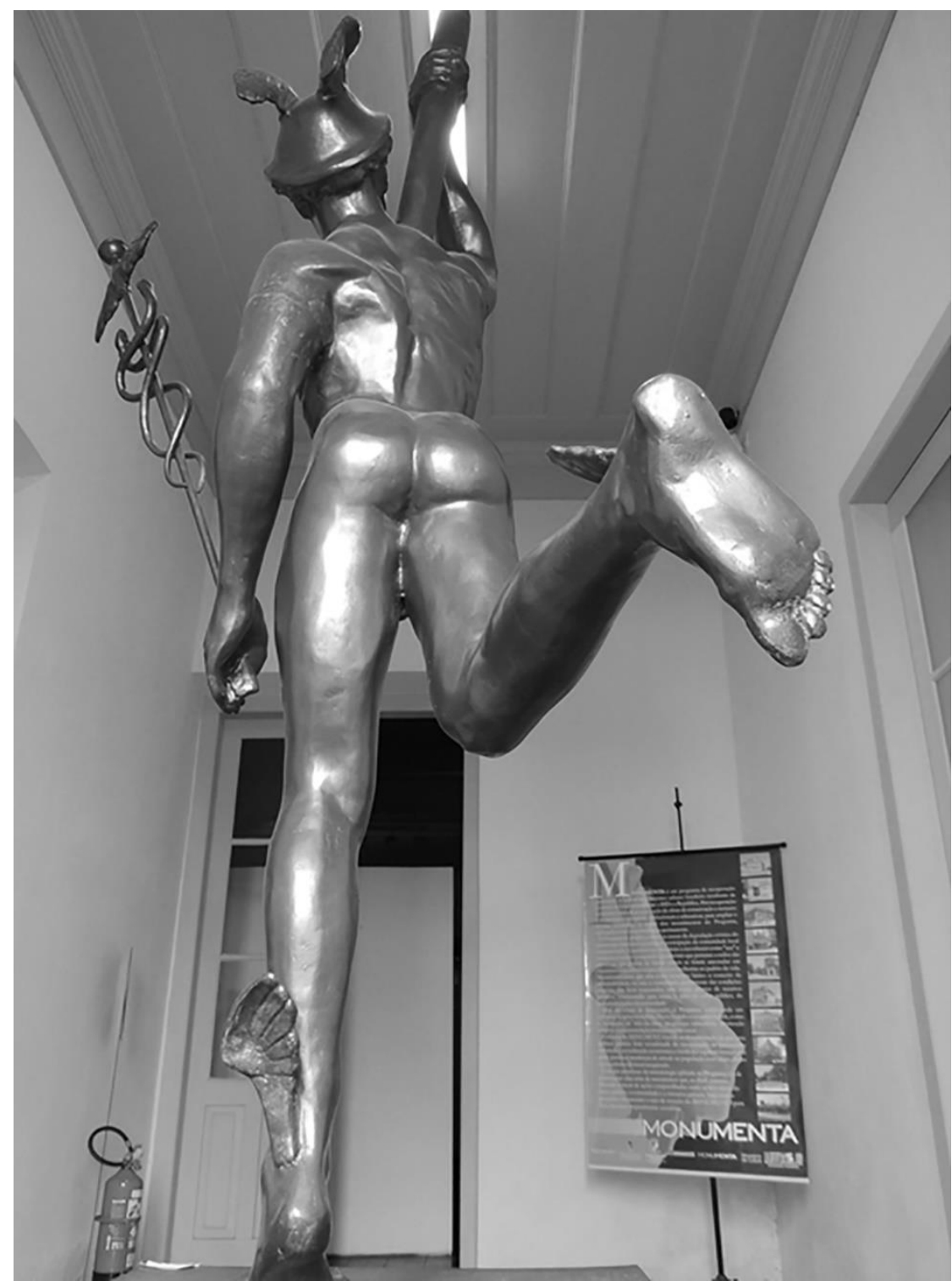

Figura 6: Fotografia da escultura de Mercúrio. Fonte: Fotografia da autora, 2013. 


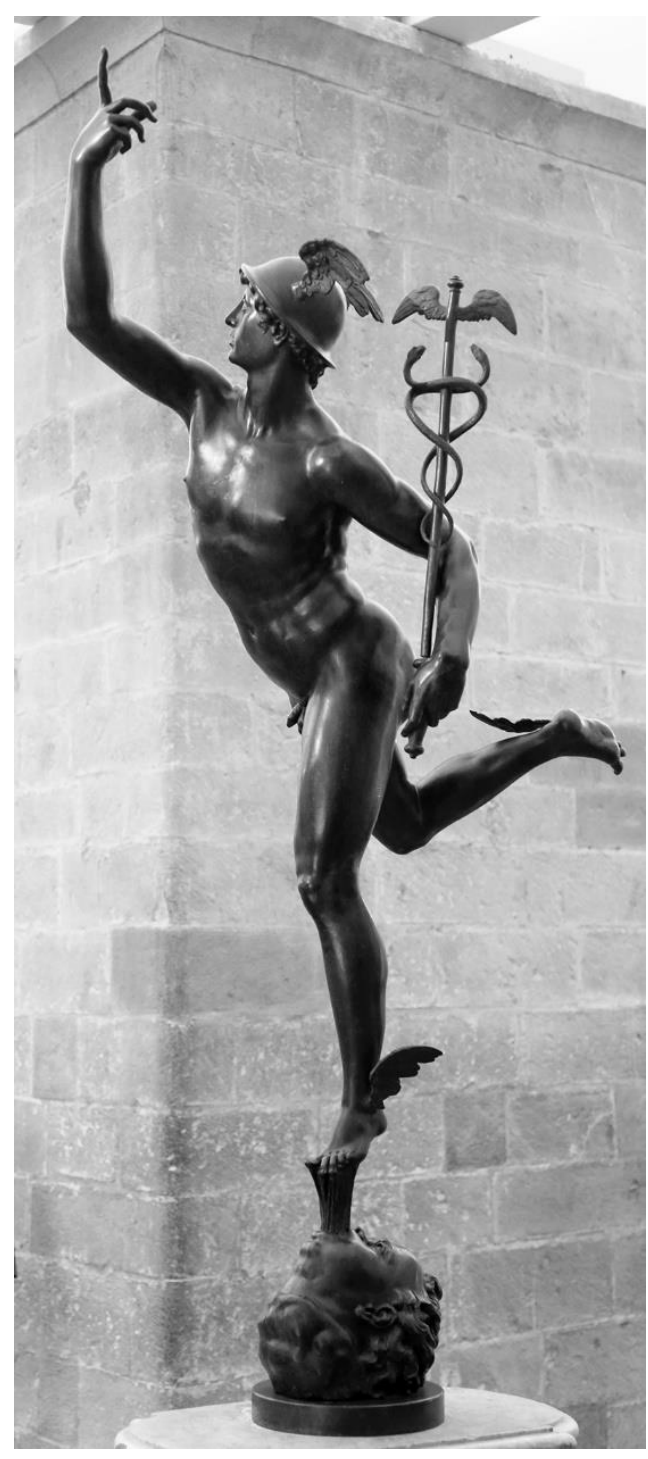

Figura 7: "Mercúrio Voador" (1589), escultura em bronze, de Giambologna, h 1,70 cm. Florença, Museu Nacional de Bargello, inv. 449 Bronzi.. Fonte: Museu Bargello. Disponível em: <http://www.polomuseale.firenze.it/musei/?m=bargello>. Acesso em: jan de 2015.

Desde que foi colocada na torre do Mercado, por volta de 1914, além da falta de documentação que comprove sua origem, a escultura percorreu uma trajetória insólita: desaparecimentos e reaparecimentos, tentativas de recuperação e intervenções de restauração mal sucedidas. No início dessa trajetória, mesmo integrando o acervo do Museu da Bibliotheca Pública Pelotense, foi retirada dessa instituição por uma família que pretendia restaurá-la. A estátua permaneceu durante décadas sob a guarda dessa, mas acabou não passando por qualquer intervenção, sendo recolhida, novamente, ao Museu da Bibliotheca Pública de Pelotas. Passados alguns anos, foi acomodada em uma pequena sala no prédio da Secretaria Municipal de Cultura, em casarão situado na Praça Cel. Pedro Osório, n. 2. Mais recentemente, foi transferida a uma sala do Mercado Central, após a 
restauração desse. Ali, no entanto, ficou em um recinto pouco divulgado e paradoxalmente "distante" do olhar da população, por não chamar a atenção do público.

Ora, essa peça havia sido inicialmente fixada no alto da torre do Mercado justamente pela alusão ao comércio que a alegoria representa e que o local incorpora. Portanto, ela só adquire sentido nesse contexto, no espaço do Mercado Central de Pelotas. Fora deste lugar e, por muito tempo, o Mercúrio sofreu um logo processo de descontextualização. Atualmente passado mais de um século de sua chegada em Pelotas e depois de passar por uma nova intervenção ${ }^{8}$ - a estátua encontra-se fixada sobre um pedestal em uma das quatro entradas do edifício, no interior do prédio do Mercado, mais próxima de seu local de origem e de pessoas que por ali circulam (Figura 8).

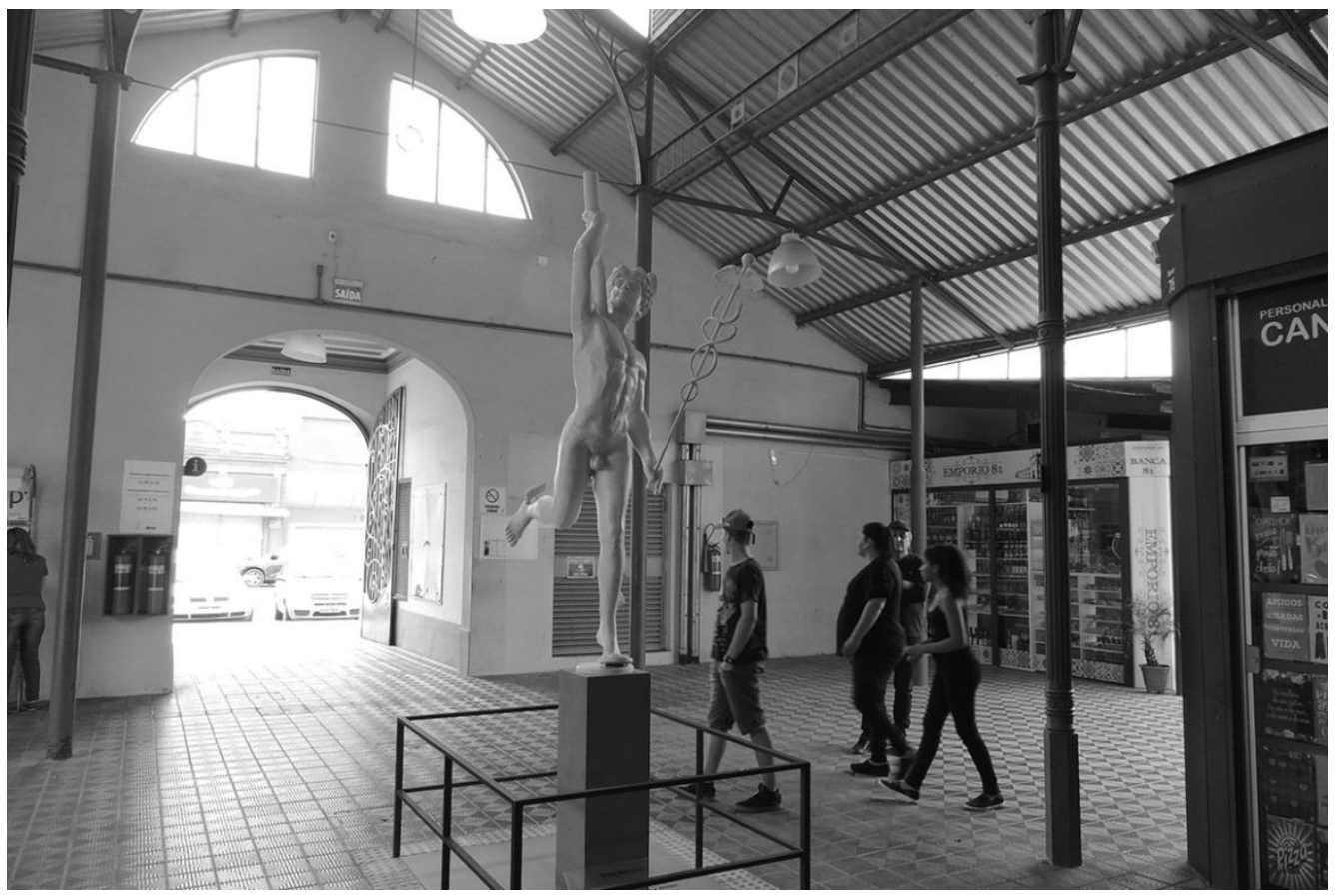

Figura 8: Localização atual da escultura. Fonte: Fotografia da autora, 2010.

Apesar de todas essas lacunas na história desse personagem em Pelotas, ocorreram inúmeras mobilizações em favor de sua patrimonialização. Esses "atores sociais", de alguma maneira, perceberam-no fora de seu contexto e se mobilizaram, mesmo que de forma intermitente, para reverter essa situação, defendendo seu retorno à torre do Mercado. Em diversas ocasiões, preservacionistas se engajaram nesse sentido, mas as

\footnotetext{
8 A estátua foi restaurada durante o primeiro semestre de 2019 pelas conservadorasrestauradoras Flávia Silva Faro e Isabel Halfen Torino. O Mercúrio não pode retornar à torre do mercado pela fragilidade estrutural que a escultura apresenta.
} 
intervenções que o Mercúrio havia sofrido tornaram sua estrutura por demais fragilizada e pesada, impossibilitando esse retorno.

\section{Origem e desenvolvimento econômico-cultural na cidade de Pelotas}

A cidade de Pelotas, no sul do Rio Grande do Sul, teve sua origem e desenvolvimento vinculados à produção do charque - carne salgada e seca ao sol, estendida em tiras sobre varais, assim conservando-a e viabilizando a sua comercialização para regiões distantes. Em 1780, a primeira charqueada instalada às margens do Arroio Pelotas deu início à atividade saladeiril, estimulando a criação de outros estabelecimentos e dando origem ao povoado que demarcaria, mais tarde, o início da cidade. Em 1812, o núcleo que se formou foi reconhecido oficialmente como Freguesia São Francisco de Paula. Em 1832, foi elevado à categoria de vila e, em 1835, recebeu o título de cidade, renomeado como Pelotas.

Em pouco tempo, a freguesia que originou a cidade, criada para "atender à indústria da carne salgada" (Gutierrez, 2004: 175), caracterizou-se como um centro comercial e de serviços de apoio à produção do charque e às atividades derivadas (produção de sebo, sabão, velas, cal). Já nas primeiras décadas do século XIX, essa indústria se firma na cidade, atrai muitos moradores novos e gera o chamado "ciclo do charque", marco decisivo para o crescimento e desenvolvimento de Pelotas, quando cria um mercado regional para o gado abundante em toda a fronteira oeste da província, intensifica consistentemente a atividade comercial e garante a "circulação e a acumulação de uma camada senhoril enriquecida" (Schlee, 1993: 71).

No apogeu econômico e cultural, entre 1860 e 1890, as riquezas advindas da indústria e comércio foram investidas na construção de edifícios e na urbanização e saneamento de Pelotas. Nesse período, a "elevação dos padrões sociais resultou no aumento dos padrões culturais", quando os valores predominantes na sociedade se ligavam às artes, letras e ciências (Magalhães, 1993: 53). Essa atmosfera cultural trouxe mudanças que aconteciam mundo afora. Pelotas desde cedo formou uma sociedade de perfil urbano, fato incomum se comparado a outras cidades do estado do Rio Grande do Sul, de índole mais rural, na opinião de Magalhães (1993, p. 233).

A cidade, quando recebeu o Mercúrio, provavelmente em 1914, já passava há algumas décadas por uma acentuada modernização e urbanização. Esse processo, iniciado na Europa no século XIX, chegou ao Brasil atingindo de 
forma mais intensa certas regiões e cidades, entre elas, Pelotas. Nesse contexto, aumentou a população urbana e a demanda por mão de obra. Impuseram-se, então, medidas voltadas ao saneamento, iluminação, moradia para operários e construção de vias para escoar a produção.

As mudanças socioeconômicas e tecnológicas na segunda metade do século XIX implicaram profundas mudanças nos modos de habitar e construir. Algumas regiões e cidades do Brasil - como Porto Alegre, São Paulo, Rio de janeiro, Recife, Fortaleza, Salvador, Belém e Manaus apresentaram crescimento mais acelerado, decorrente da produção e exportação de produtos agrícolas como açúcar, café, algodão e borracha, entre outros. O rápido desenvolvimento desses locais exigia que se construísse mais e com maior rapidez, adaptando as cidades a essas mudanças (Kühl, 1998: 83).

Testemunhas de um momento efervescente, as pessoas, encantadas, acompanhavam as inovações trazidas pela modernização e progresso, admirando os símbolos da modernidade, ainda que algumas vezes tocados muito indiretamente por eles. Nasce uma "vontade de ser moderno" (Fabris, 1993: 137). Nesse clima, contaminado pelo desejo de modernidade e progresso - iniciado na Europa, mas que atingiu outros países ainda no século XIX - Pelotas cresceu, absorvendo essas mudanças.

O ferro, empregado desde a Antiguidade com fins utilitários, transformouse, com o desenvolvimento industrial, em matéria prima para a fundição artística. Tornou-se um componente expressivo das paisagens urbanas do século XIX, com papel importante. Inicialmente, surgem os encanamentos de ferro fundido e as máquinas a vapor ${ }^{9}$. A seguir, ferrovias, estações ferroviárias e a "arquitetura do ferro" completam o quadro de modernidade e progresso, proporcionando mobilidade e rapidez, tão desejadas à época. Durante a "civilização do ferro" (Silva, 1986), aportou em Pelotas um expressivo patrimônio metálico, constituído por reservatórios d'água e chafarizes, alguns importados da Alemanha, outros da França. Surgem ainda estruturas construtivas, como as que se incorporam ao Mercado Central, como a cobertura e a torre, a qual foi coroada com a escultura do "Mercúrio Voador".

\footnotetext{
${ }^{9} \mathrm{O}$ barco a vapor foi inventado nos Estados Unidos, em 1805, e, na década de 1830, foi fabricada a primeira embarcação a vapor no Brasil, justamente em Pelotas. A locomotiva foi inventada na Inglaterra, em 1814.
} 


\section{O legado clássico em Pelotas}

O Brasil, no final do século XIX, recebeu muitos imigrantes e, entre eles, arquitetos e construtores. Além da presença desses imigrantes, que traziam suas concepções próprias, "o critério de gosto da elite dirigente, que deseja reproduzir no Brasil tipos e modelos admirados na Europa", é um fator importante a considerar na afirmação do ecletismo no país ${ }^{10}$. Entretanto, não se trata de mera imitação de obras ou ideias em voga na Europa; a "importação cultural" foi mais profunda e, para entendê-la, segundo Fabris (1993: 136), é preciso buscar "de que modo ocorreu essa importação, que elementos foram escolhidos e adotados e qual foi o produto resultante dessa operação".

Observa-se, aqui, um importante aspecto relativo à recepção da Antiguidade: a ideia de modernidade das últimas décadas do século XIX em Pelotas passava por um ideal de Antiguidade delineado na Europa, mas redefinido no Brasil. Naquela época, as casas da elite local, construídas até aproximadamente 1860 em estilo colonial, configuram-se em novo estilo - o ecletismo - com elementos da Antiguidade clássica e da Renascença italiana, principalmente na ornamentação das fachadas.

Marshall (2005: 21) refere-se a um império do imaginário clássico sobre a mente do homem moderno, vivido intensamente nos séculos XV e XVI. Esse domínio, segundo o autor, "se estende até a Primeira Grande Guerra, alimentando variados projetos históricos em sucessivos neoclassicismos e revalidando, a cada geração, a potência criadora da inteligência antiga, assim como o espetacular efeito persuasivo de seus produtos culturais".

Na urbanização de Pelotas, a arquitetura se apropriou de elementos da cultura clássica, materializados nas alegorias da nossa iconografia urbana, hoje resultando em um número expressivo de bens hierarquizados e classificados como patrimônio móvel e imóvel, sendo parte integrante da paisagem urbana atual. Nas fachadas de alguns prédios - principalmente as edificações da segunda metade do século XIX e início do XX - estão presentes elementos clássicos (colunas dóricas, jônicas e coríntias, arcos romanos e frontões gregos), além de um conjunto de imagens herdadas da arte e cultura greco-romana, fixadas em estátuas de porcelana encimando

\footnotetext{
10 Como expressão cultural desse momento ímpar de desenvolvimento, modernidade e efervescência cultural em Pelotas, o ecletismo iniciou na cidade em 1870, estendendo-se aproximadamente até 1930. Nessa transição, os modelos coloniais presentes na cidade passaram a ser substituídos pelos da arquitetura eclética, sendo incorporados nas fachadas dos prédios elementos compositivos variados, mas que expressavam vínculo com algum período do passado.
} 
platibandas, mármore, bronze ou ferro, chafarizes, fachadas ornamentais ou figurativas, tetos de estuque ou estuques em relevo.

A forma com que Pelotas dialoga com o passado, manifestada no sentimento de valorização e proteção do seu patrimônio - parte dele ainda bem preservada - revela o modo como a população, ou pelo menos parte dela, recebe essa herança clássica e como se identifica com ela. Os atuais habitantes - pelo menos alguns deles - respondem positivamente a essa "apropriação contemporânea" da cultura greco-romana, que faria alusão a uma época próspera que a cidade viveu no passado. Tais monumentos, mesmo que valorizados de diferentes formas pela população local, seriam um testemunho do papel da recepção da Antiguidade na formação de nossa identidade cultural e de nosso patrimônio cultural nacional, visto que esses elementos estavam (e estão) presentes em outras cidades que tiveram ciclo de prosperidade coetâneo a Pelotas.

Nesse sentido, a presença de Mercúrio na torre do Mercado Central não foi um fenômeno isolado, pois o acompanhavam outros Mercúrios no Brasil e em Pelotas. Portanto, havia um contexto visual em que se inseria nosso Mercúrio de Giambologna, contexto que integrava a identidade urbana então considerada "moderna".

\section{Representações de Mercúrio em Pelotas}

Devido à transformação da paisagem urbana de Pelotas desde o final do século XIX, importantes traços da presença de Mercúrio desapareceram do cenário. No centro histórico, em contraste com a presença maior de Apolo, acompanhado das musas e seus atributos, a escassez das imagens de Mercúrio pode gerar uma falsa impressão. Hoje, além da escultura do Mercado Central, perduram poucos testemunhos das representações alusivas ao Mercúrio: o Mercúrio da fachada do Clube Caixeiral, acompanhado de Vulcano; sobre a platibanda do palacete do Visconde de Jaguari11 (Figuras 9 e 10), uma alegoria ao comércio, reconhecível pelo caduceu pouco perceptível em sua mão direita, vincula-se à simbologia de Hermes; por fim, a cabeça de Mercúrio em um dos capiteis do prédio do antigo Banco Nacional do Comércio (Figura 11). Na virada do século, a figura de Mercúrio provavelmente seria muito mais comum aos olhos dos habitantes, visto que havia ainda outros Mercúrios, hoje desaparecidos em sua materialidade escultórica.

11 Sede atual do Cartório Lorenzi.

Heródoto, Unifesp, Guarulhos, v. 4, n. 2, 2019.2 p. 206-240

DOI: $10.34024 /$ herodoto.2019.v4.10973 


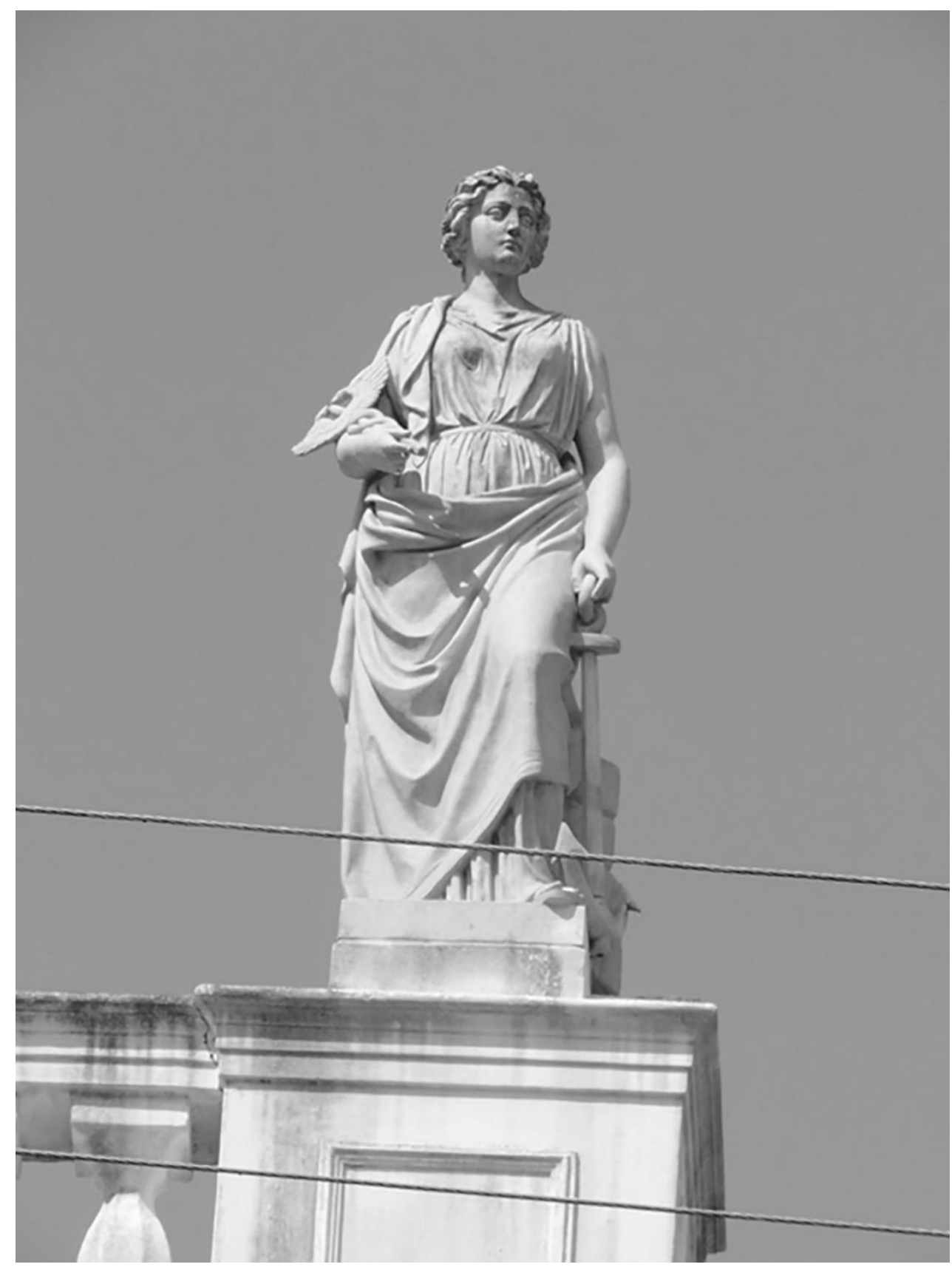

Figura 9: Estátua de cimento: alegoria ao comércio com atributo de Mercúrio. Platibanda do edifício do atual Cartório Lorenzi. Fonte: fotografia da autora, 2016. 


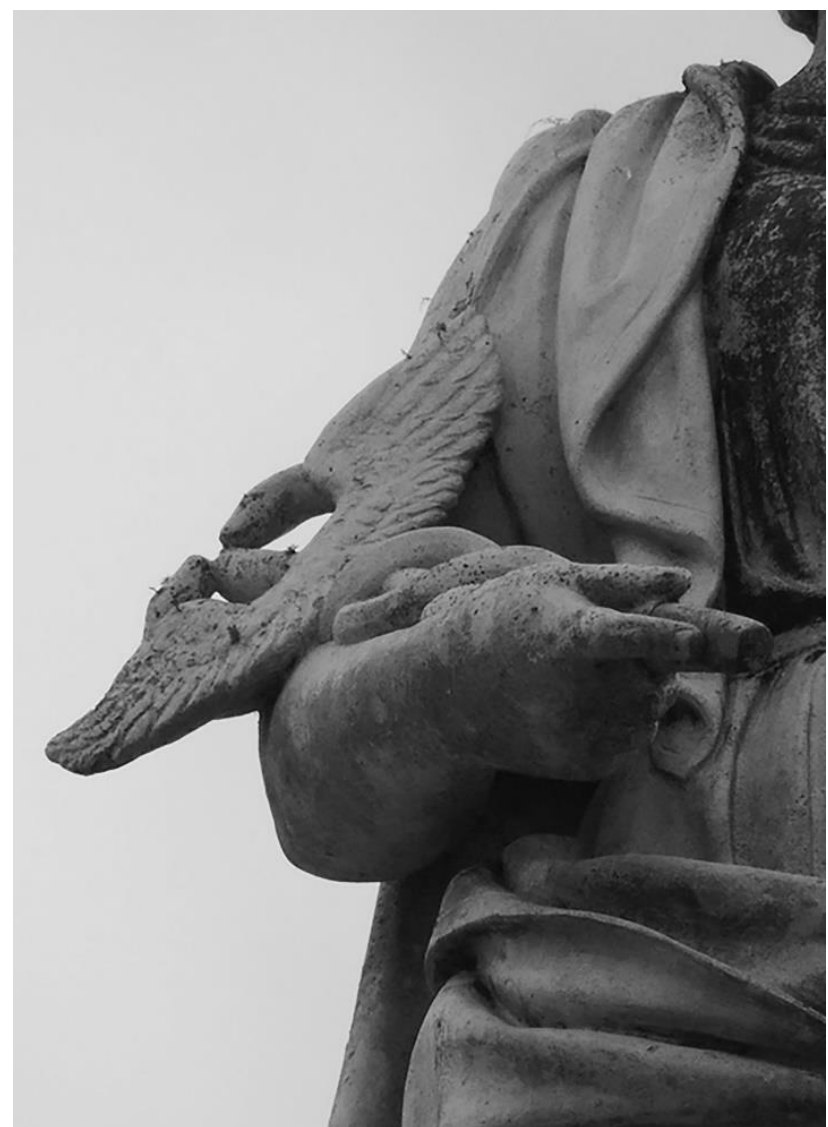

Figura 10: Detalhe da figura anterior. Caduceu no braço direito da estátua. Fonte: fotografia da autora, 2016.

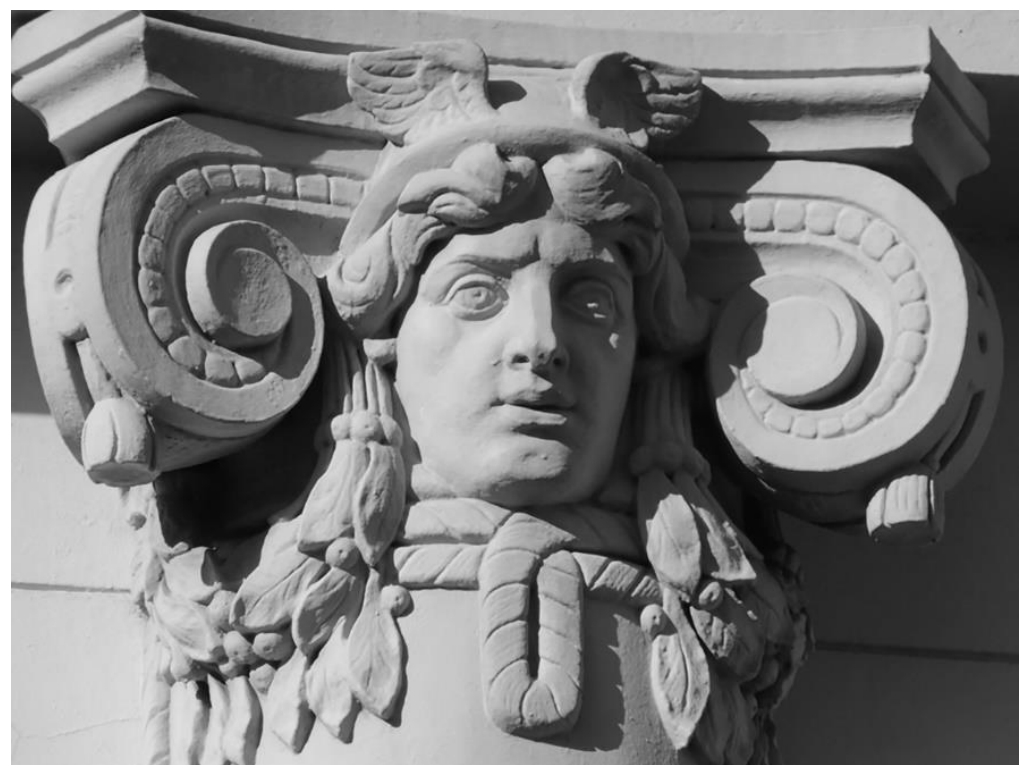

Figura 11: Capitel em volutas com cabeça de Mercúrio, com capacete alado. Fonte: fotografia da autora, 2014.

Segundo Carlos Alberto d'Ávila Santos (2007: 318), no período de desenvolvimento do estilo eclético, dentre os principais adornos de estuque ou cimento nos estabelecimentos comerciais, destacavam-se as representações de Hermes ou Mercúrio, associadas às funções dos 
edifícios. $\mathrm{O}$ autor enfatiza, ainda, que esculturas de divindades gregas como Hefesto, Hermes, Apolo, Atena e Demeter, foram incorporadas à decoração da fachada de casas bancárias e assim "identificadas com as origens dos capitais depositados e gerenciados por essas empresas, oriundos da indústria, do comércio e da agricultura". Em fachadas de clubes, acrescentavam "máscaras, instrumentos musicais e estátuas de gosto clássico, representando ninfas, musas e os deuses mitológicos Apolo, Vulcano e Mercúrio, atrelados às origens econômicas dos associados e às atividades culturais ou recreativas" (Santos, 2007:75).

A fachada do Clube Caixeiral, construído em 1904 pelo arquiteto Caetano Casaretto, de origem italiana, é repleta de referências ecléticas. Sua estrutura e decoração são ricas em citações da Antiguidade, como pilastras, colunas, óculos, platibandas vazadas e cegas, frontões curvos e figuras mitológicas gregas. Na fachada principal, vemos quatro referências mitológicas. No plano inferior, mais próximo do olhar dos transeuntes, uma musa com um livro aberto e Apolo citaredo, simbolizando assim as Letras e a Música. Com essas divindades, conota-se que a educação e a cultura estão na base da riqueza, indicadas pelas duas figuras dispostas no plano superior: à esquerda, Hefesto ou Vulcano com seus atributos (o capacete, a bigorna e o martelo); à direita, Hermes ou Mercúrio, com uma âncora, um barril e uma canastra (Figura 12).
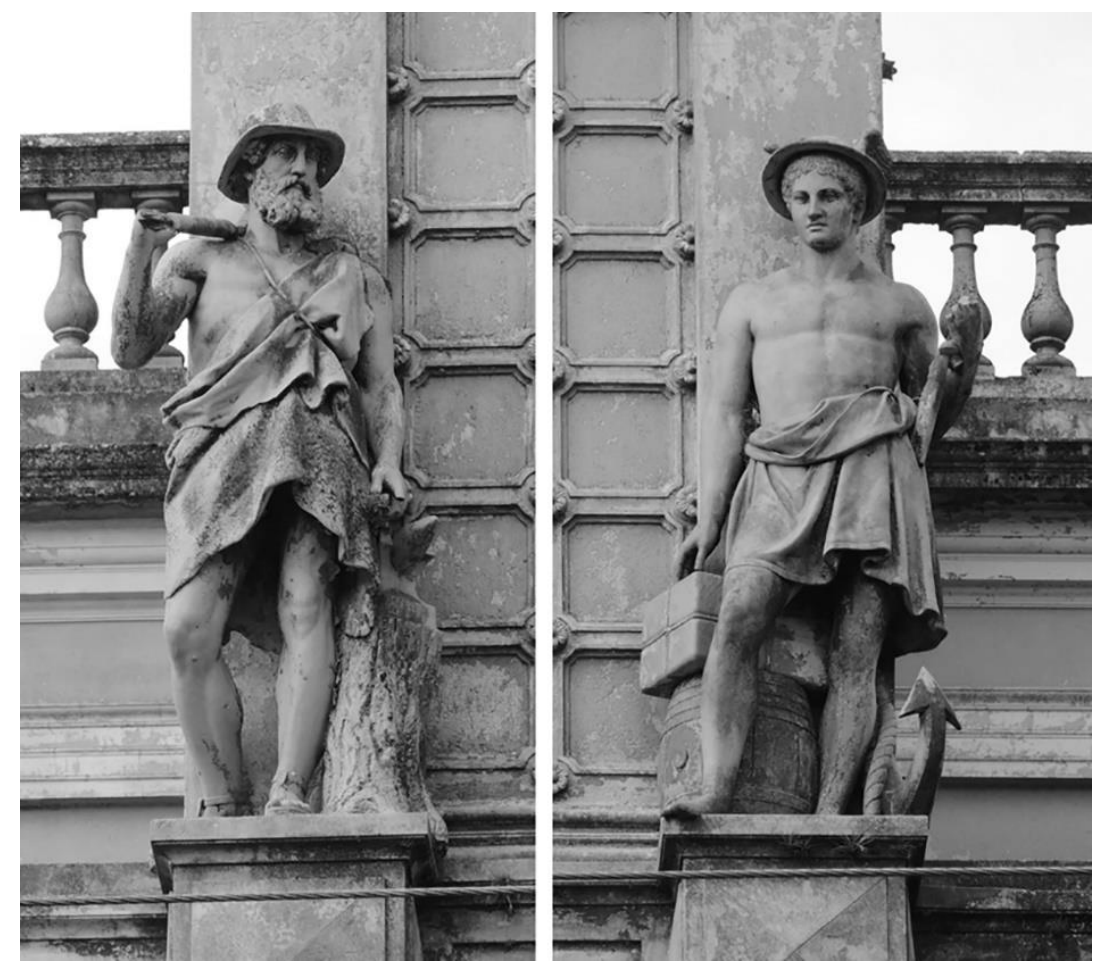

Figura 12: Esculturas de Vulcano (esquerda) e Mercúrio (direita). Fonte: fotografia da autora, 2016. 
Duas expressivas presenças de Mercúrio na arquitetura da Belle Époque pelotense podem ser contempladas hoje tão-somente em fotografias, que testemunham uma época em que a cidade liderava o mercado editorial do Rio Grande do Sul. Trata-se das livrarias Americana e Universal, cujos edifícios ostentavam, incorporadas às suas fachadas, esculturas de Vulcano e Mercúrio. Lamentavelmente, esses prédios não se preservaram.

A Livraria Americana, a mais antiga, fundada em 1875, foi a pioneira no Estado. Inicialmente na Rua Andrade Neves, transferiu-se em 1891 para um prédio próprio na Rua XV de Novembro, no 195 (Figura 15). Esse apresentava, em sua fachada, um complexo programa iconográfico, com a platibanda encimada pelas figuras de Hefesto/Vulcano e Hermes/Mercúrio ${ }^{12}$.

A Livraria Universal, fundada doze anos após a Americana, em 1887, instalou-se em um prédio na rua XV de Novembro, entre as ruas General Neto e Sete de Setembro. Em 1893, transferiu-se para sua loja nova, construída para esse fim, em um dos pontos mais populares da cidade, a "Esquina 22", entre ruas XV de Novembro e Sete de Setembro (onde hoje está a matriz da Caixa Econômica Federal em Pelotas). Em destaque, ladeando as entradas do estabelecimento, estavam as estátuas de Vulcano e Mercúrio (Figuras 13 e 14), provavelmente de cimento. Muito próximas dos transeuntes, mantinham relação estreita com o cotidiano do centro da cidade.

Como aponta Mario Osório Magalhães (2003), a presença dos deuses greco-romanos na fachada da Americana era usada na propaganda da empresa nos jornais da época: "Casa nova de colunas encarnadas com grandes estátuas em cima" - é como os proprietários anunciavam em 1891, o que foi desdenhado pela concorrente naquele momento. Apesar disso, dois anos mais tarde, a mesma Universal, quando inaugurou sua sede nova, emulou a concorrente mais antiga. No novo prédio, colocou as figuras de Vulcano e Mercúrio na fachada. Mas não se limitou a copiar. Inovou na localização das imagens. De forma mais explícita, acreditando na vantagem da exposição das imagens, a Universal as inseriu próximas à base do prédio, ao lado da entrada, em contato visual direto com o público. Isso indica como, para a percepção de então, a representação dessas divindades antigas simbolizava fortemente a função social desse tipo de estabelecimento, consideradas ademais eficientes do ponto de vista do marketing.

12 A Livraria Americana encerrou suas atividades em 1916, quando foi adquirida pela concorrente, a Livraria Universal Echenique (Arriada e Tambara, 2014:243). 
É interessante observar ainda que as figuras de Mercúrio e Vulcano das duas livrarias seguem o mesmo modelo das estátuas da fachada do Clube Caixeiral (Figura 12), embora separadas por quase vinte anos. Neste modelo, trata-se a imagem dos deuses antigos numa concepção aggiornata, incorporando elementos da época aos seus atributos clássicos.

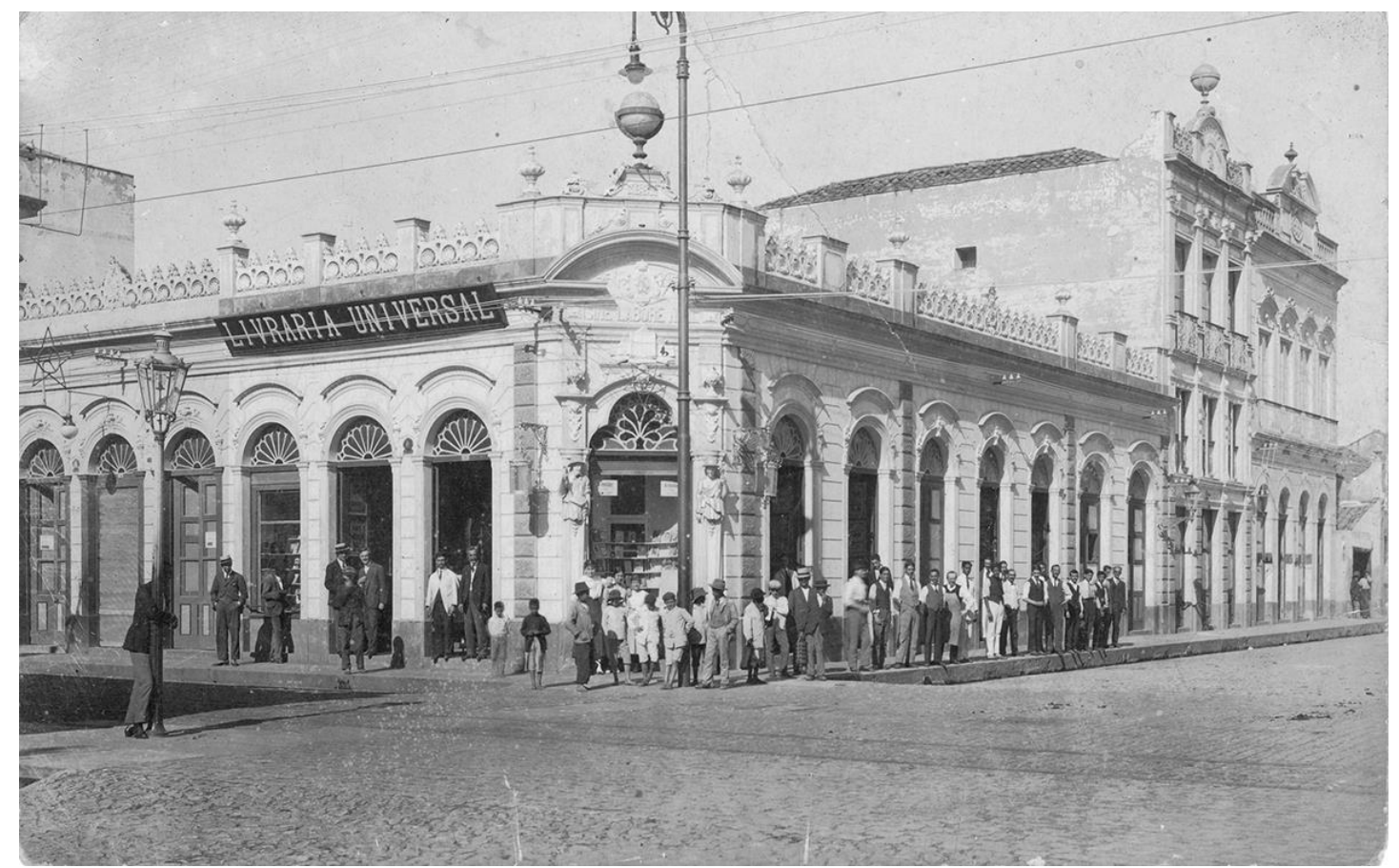

Figura 13: Cartão postal com fachada da Livraria Universal. Fonte: Acervo do Instituto Histórico e Geográfico de Capão do Leão. 


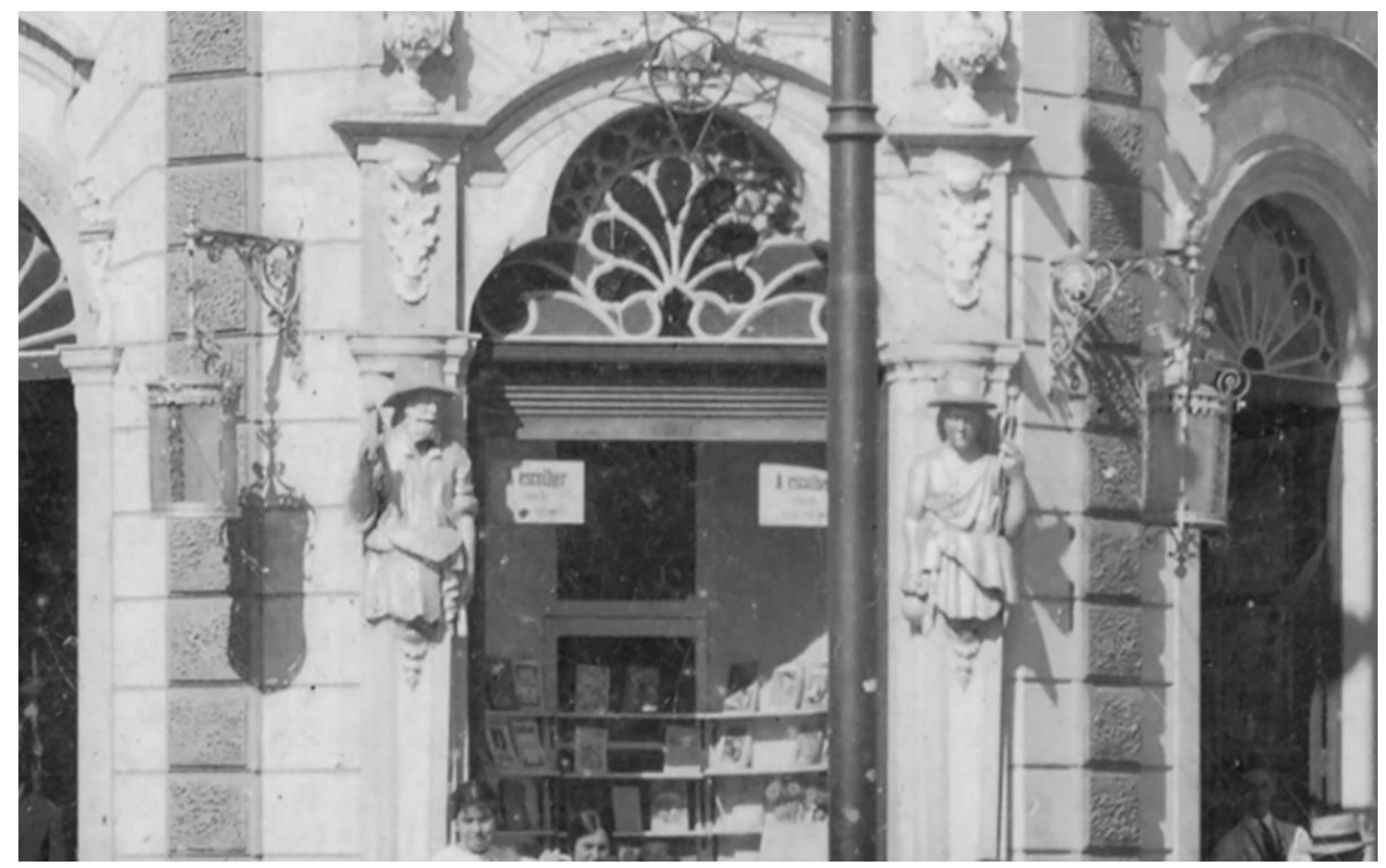

Figura 14: Detalhe de cartão postal com fachada da Livraria Universal. Fonte: Acervo do Instituto Histórico e Geográfico de Capão do Leão. 


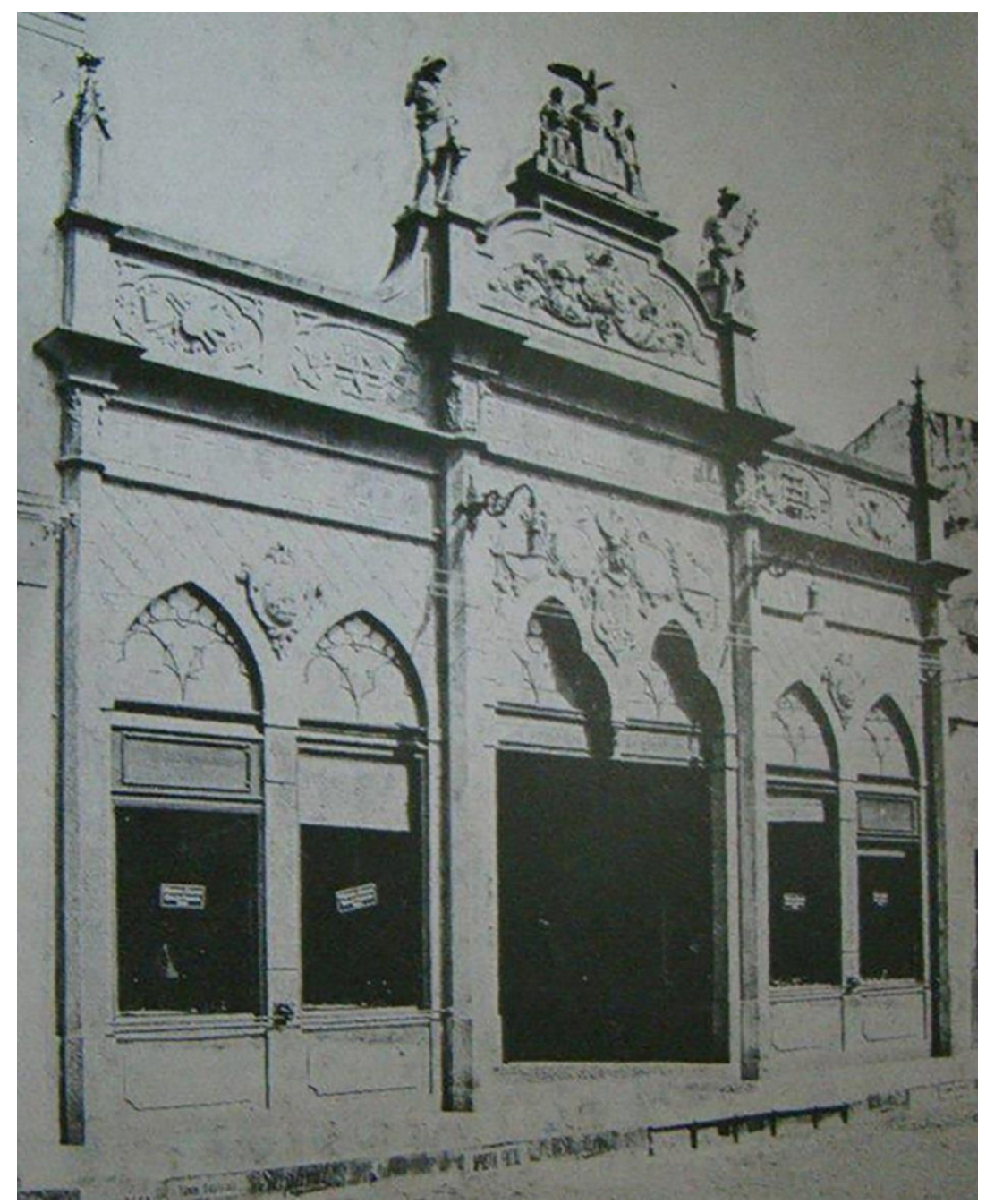

Figura 15: Fachada da Livraria Americana, com frontão encimado por Vulcano e Mercúrio. Fonte: Acervo Eduardo Arriada.

\section{Os Mercúrios do Brasil}

Cidades brasileiras como Manaus, Rio de Janeiro e Recife, entre outras, tiveram em comum com Pelotas um importante "ciclo de prosperidade" na chamada Belle Époque brasileira ${ }^{13}$. Período de apogeu econômico e cultural em que, combinados com a decoração urbana e arquitetônica, os elementos ornamentais contribuíam para materializar símbolos de poder, de riqueza e de civilização.

Muito embora se reconheça que havia níveis de apropriação do clássico que variavam conforme a localidade e que suas diferenças podem ser reconhecidas na relação entre formas arquitetônicas e ornamentos,

13 Manaus teve o "ciclo da borracha", ocorrido na Região Amazônica; Rio de Janeiro e Londrina, o "ciclo do café", e Recife, o "ciclo da cana-de-açúcar".

Heródoto, Unifesp, Guarulhos, v. 4, n. 2, 2019.2 p. 206-240

DOI: $10.34024 /$ herodoto.2019.v4.10973 
percebe-se uma sincronia entre os "Mercúrios Voadores" de Pelotas, Manaus, Rio de Janeiro e Recife. Já o Mercúrio de Londrina, mesmo que igualmente no modelo de Giambolgna, é mais recente, vinculado a outro momento histórico.

Ainda que outras esculturas representando Mercúrio possam ser encontradas no Brasil, serão destacadas aqui as que seguem o modelo de Giambologna, acreditando-se haver um diálogo entre elas, como uma característica cultural desse período. No país, do ponto de vista do reconhecimento patrimonial, destacam-se os exemplares do Rio de Janeiro e Manaus. Coincidência ou não, foram produzidos pela Fundição Val d'Osne ${ }^{14}$ (Figura 16), contemporânea e concorrente da Fundição Durenne, responsável pelos chafarizes de Pelotas. Foram instalados em datas muito próximas às estátuas de Pelotas e do Recife, estas de fabricação não identificada: a primeira foi a de Manaus, em 1906, a última deste ciclo, a de Recife, em 1915.

${ }^{14}$ A produção das fundições francesas é bem conhecida através dos catálogos editados pelos fundidores nos anos 1840. Nos catálogos da Val d'Osne consta, junto às peças, a identificação dos autores e a procedência das obras. 

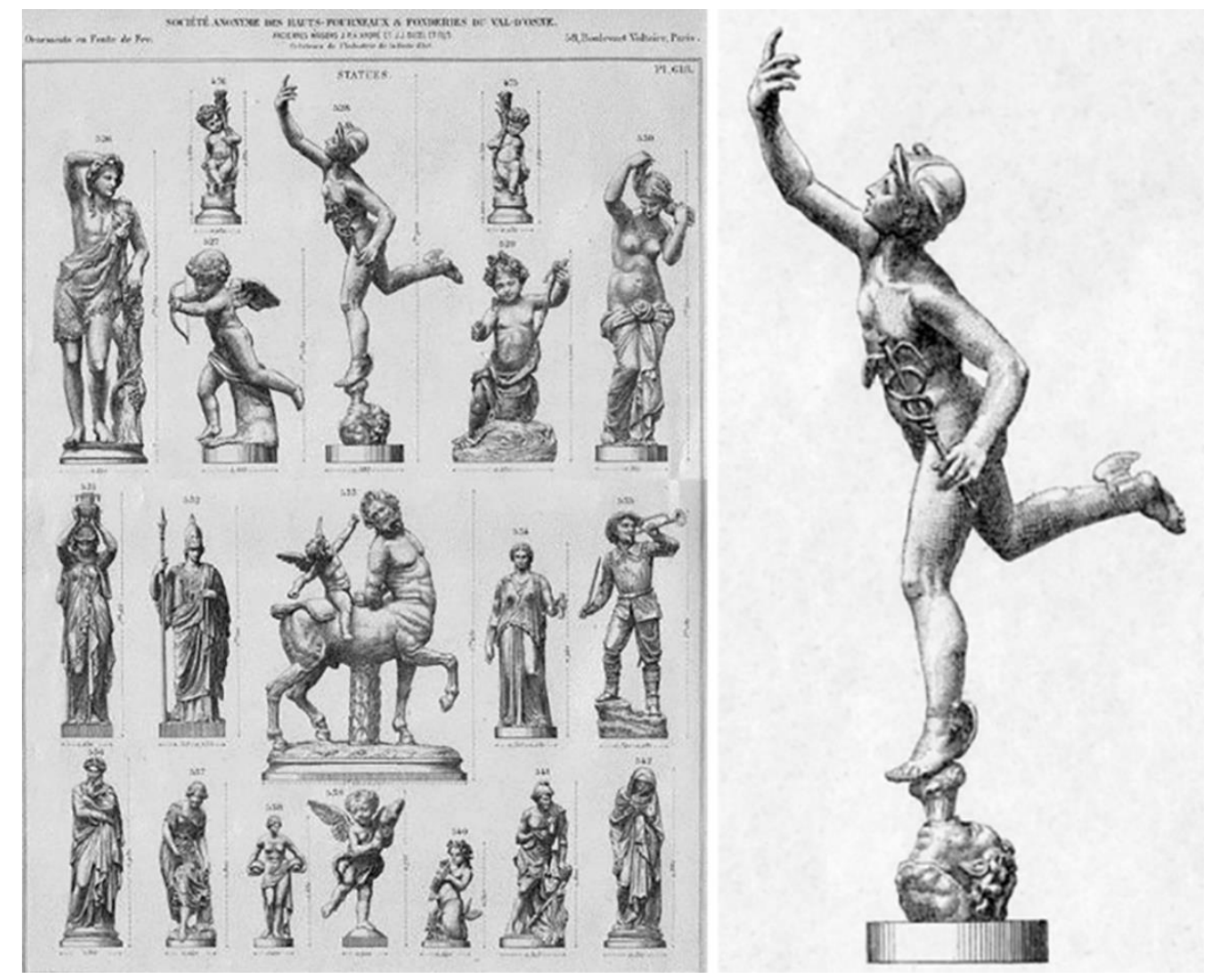

Figura 16: Catálogo da Fundição Val d' Osne, álbum n ${ }^{\circ}$ 2, prancha 618-528 (esquerda). O modelo do Mercúrio de Giambologna em detalhe (direita). Fonte: Disponível em: < https://e-monumen.net/patrimoine-monumental/vo2_pl618-statues/>. Acesso em: out 2019.

\section{O Mercúrio de Manaus}

A Praça Heliodoro Balbi ${ }^{15}$, que abriga o Mercúrio manauara, no Amazonas, originou-se na década de 1870, mas começou a receber melhorias quase vinte anos mais tarde. A estátua foi colocada em 1906 ou 1907, juntamente com um coreto e uma fonte de ferro fundido, além de outras esculturas.

O site eletrônico E-Monumen.net disponibiliza, através de uma base de dados geolocalizados, um "mapa do patrimônio francês no mundo". Este informa que o modelo em ferro do Giambologna colocado na Praça Heliodoro Balbi em 1906 (Figura 17) foi produzido pela Val d'Osne (Figura $18)^{16}$

\footnotetext{
15 Também conhecida como Praça da Polícia (DUARTE, 2009, p. 40).

${ }^{16}$ Catalogue Val d'Osne - album n $n^{\circ}$ 2, prancha 618, 528 e correspondente à figura 15.
} 


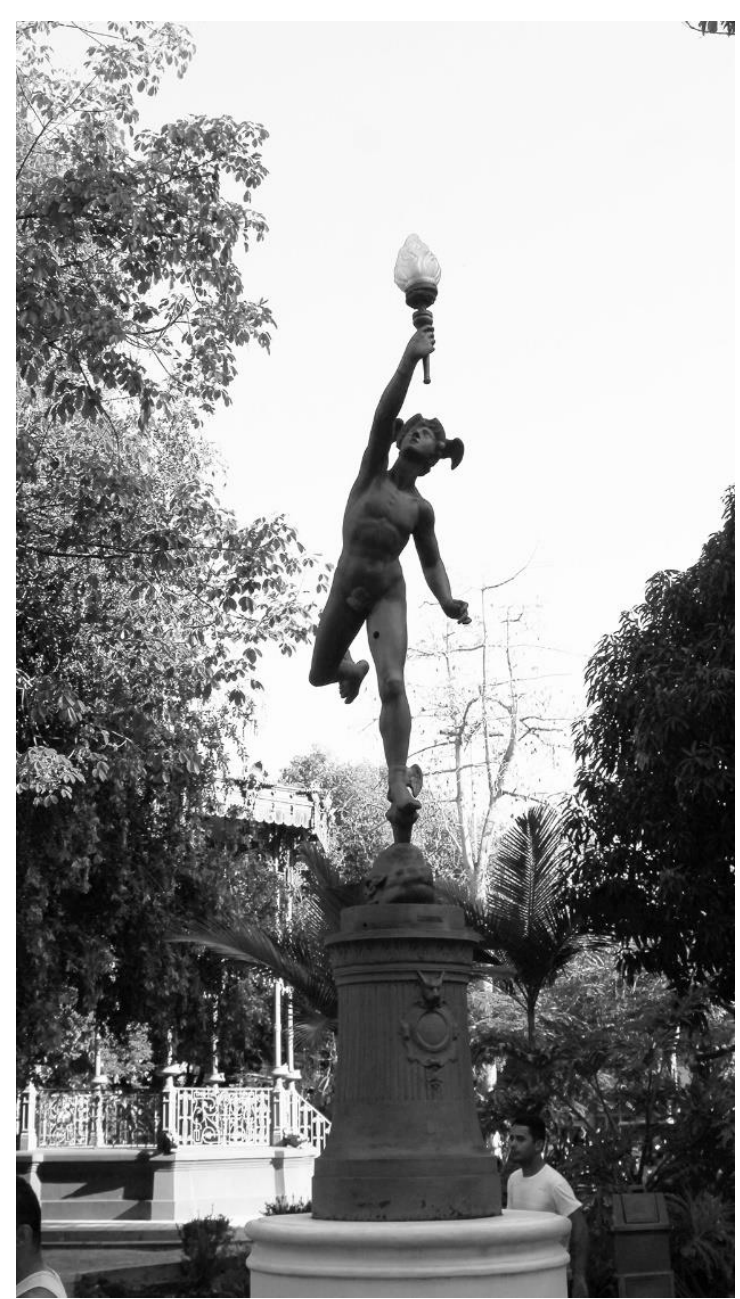

Figura 17: Escultura em ferro $(1,90 \mathrm{~cm})$ de Mercúrio, na Praça Helliodoro Balbi, Manaus. Ao fundo, o coreto de ferro fundido. Fonte: Disponível em: <http://emonumen.net/patrimoine-monumental/mercure-praca-balbi-manaus/\#priceblock2>. Acesso em: out 2019.

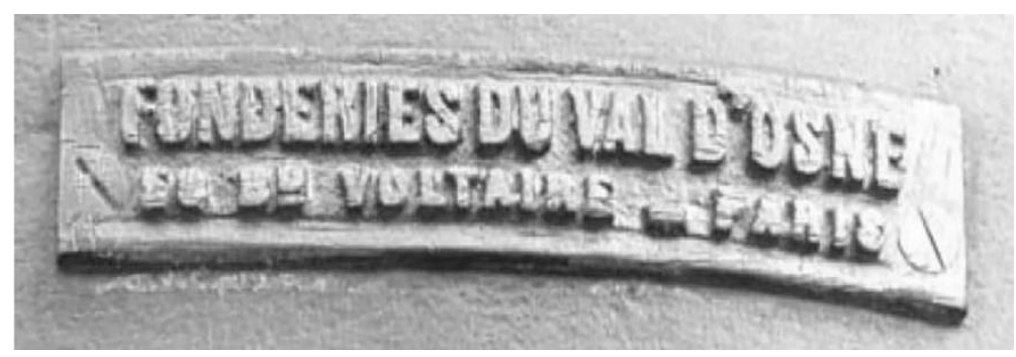

Figura 18: Placa da fundição Val d'Osne, que realizou a escultura do Mercúrio de Manaus. Fonte: Disponível em: <http://e-monumen.net/patrimoinemonumental/mercure-praca-balbi-manaus/\#priceblock2>. Acesso em: out 2019.

A apresentação atual da escultura de Manaus difere da figura do catálogo na luminária erguida por Mercúrio com a mão direita (Figura 17) e na ausência do caduceu. Há duas hipóteses: ou o caduceu foi perdido quando a praça, suas esculturas e elementos ornamentais passaram por um período de abandono, ou isso pode ter sido resultado de alguma intervenção. Segundo Duarte (2009, p. 40), a praça sofreu uma grande reforma e 
"melhorias" em 1922. Mais recentemente, as peças de ferro fundido foram restauradas ${ }^{17}$. A intervenção foi finalizada em 2009, assim como a restauração do Palacete Provincial, complexo que abriga seis museus, laboratório de arqueologia e ateliê de restauração.

\section{O Mercúrio do Rio de Janeiro}

O prédio do Palácio das Laranjeiras (Figura 19), no Rio de Janeiro, foi construído entre 1909 e 1913 pelo arquiteto Armando Carlos da Silva Telles, para servir de residência à família Guinle, concessionária do porto carioca. Em 1947 foi comprado pelo Governo Federal e usado como residência presidencial até a inauguração do Palácio da Alvorada, em 1960, em Brasília. Atualmente é a residência oficial do governador do estado do Rio de Janeiro.

Uma escultura em ferro fundido do deus Mercúrio, quase idêntica à de Manaus, colocada em frente à escadaria do palácio, aponta para o céu. A prancha de identificação da fundição Val d'Osne, segundo o site EMonumen.net, informa a data de 1913 como instalação do monumento. Fiel ao modelo de Giambologna, a escultura do Rio de Janeiro (Figura 20), no lugar da luminária presente no exemplar manauara, preserva o atributo original, o caduceu.

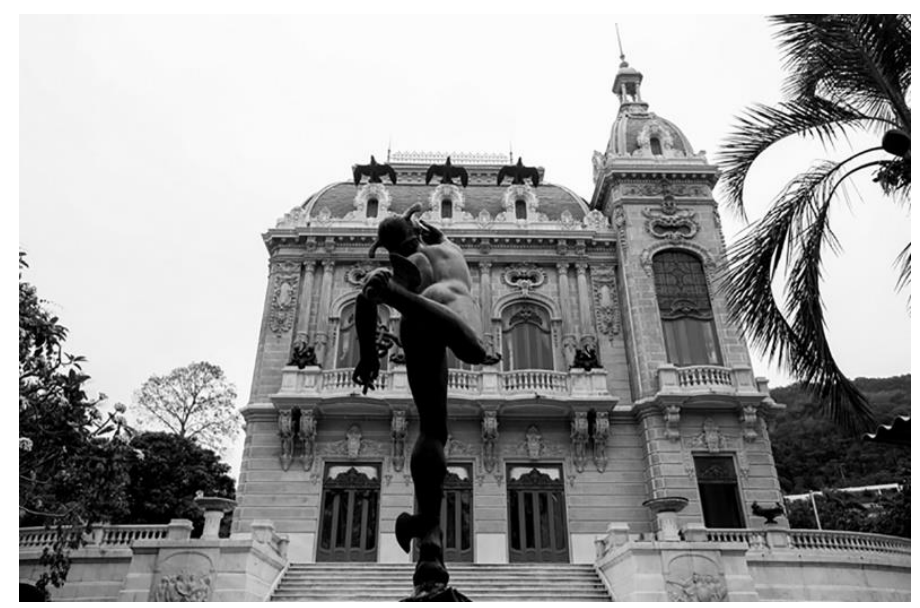

Figura 19: Mercúrio Voador nos jardins do Palácio das Laranjeiras. Fonte: Disponível em: <http://oglobo.globo.com/rio/rio-450/mobiliario-historico-acervo-de-obras-dearte-do-palacio-das-laranjeiras-serao-recuperados-14065506>. Acesso em: out 2019.

17 A restauração contou com a consultoria de Nicola Salvione, especialista italiano em metais. 


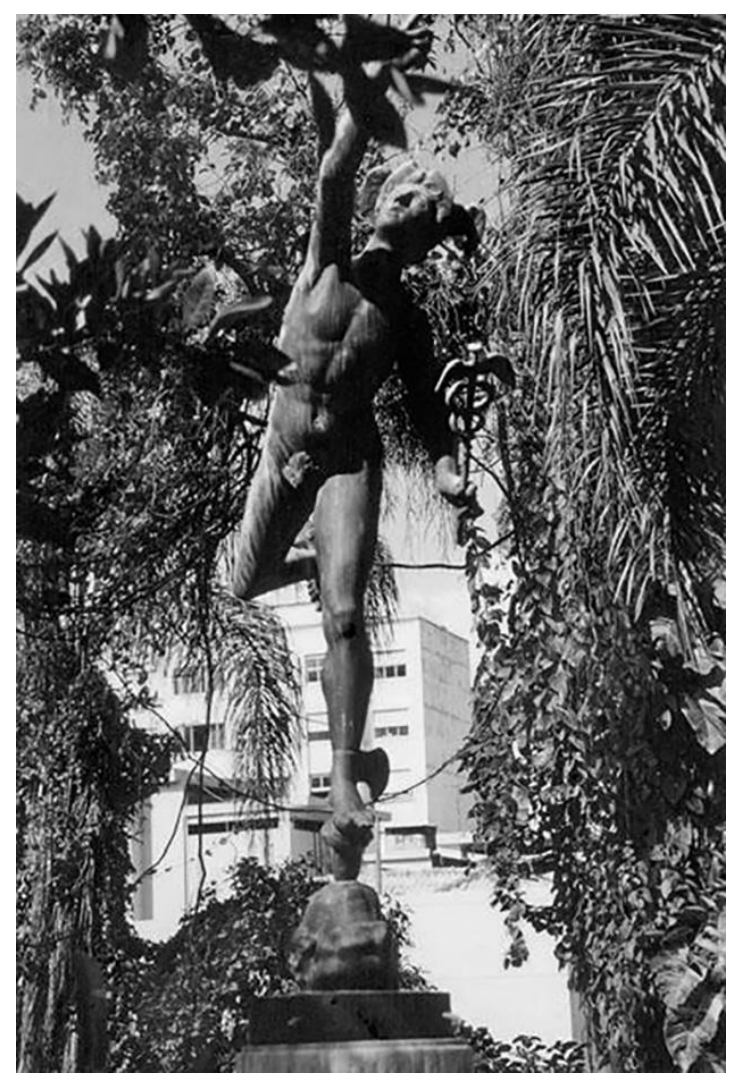

Figura 20: Mercúrio Voador no Palácio das Laranjeiras no Rio de Janeiro. Fundição Val d'Osne. Fonte: Disponível em: <http://e-monumen.net/patrimoinemonumental/statue-le-mercure-palais-de-laranjeiras-estatua-o-mercurio-palacio-delaranjeiras-rio-de-janeiro>. Acesso em: out 2019.

\section{O Mercúrio de Recife}

O prédio da Associação Comercial de Pernambuco foi inaugurado em 1915 (Figura 21). Em estilo eclético, possui, entre outros elementos, uma escadaria de ferro inglesa, pinturas murais e de teto, um conjunto de 20 vitrais e lustres. Tombado pelo IPHAN, o edifício, após restauração, foi reinaugurado em 2008.

No frontão que encima a fachada, havia originalmente um conjunto escultórico formado por três elementos: ao centro e acima, Mercúrio, segurando uma âncora, em referência ao mercado marítimo recifense, entre duas figuras femininas sentadas, talvez musas (Figuras 21 e 22). Essas peças estão desaparecidas. 


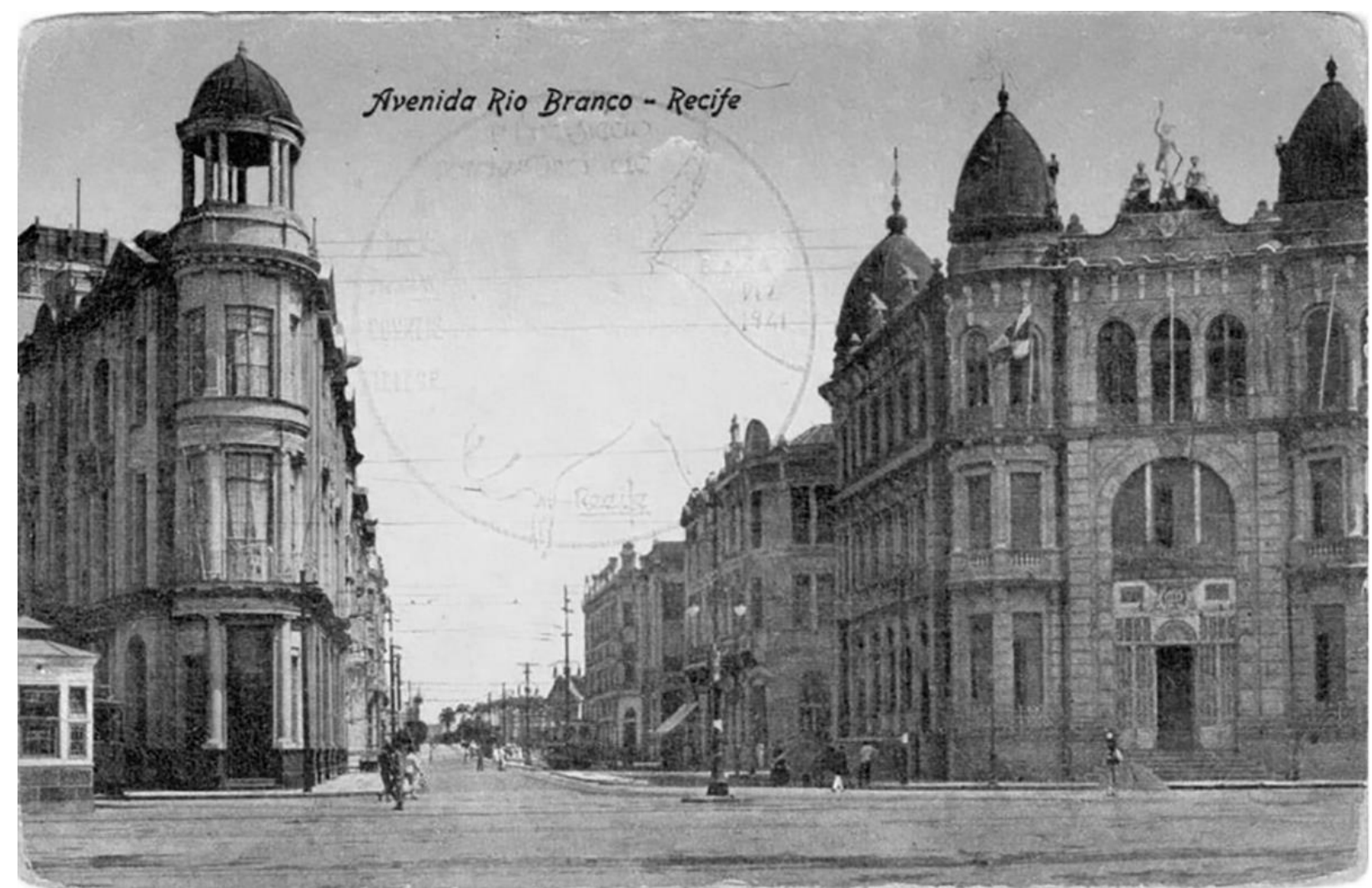

Figura 21: Associação Comercial de Pernambuco em 1915 (direita). Fonte: Núcleo de digitalização Fundação Joaquim Nabuco. 


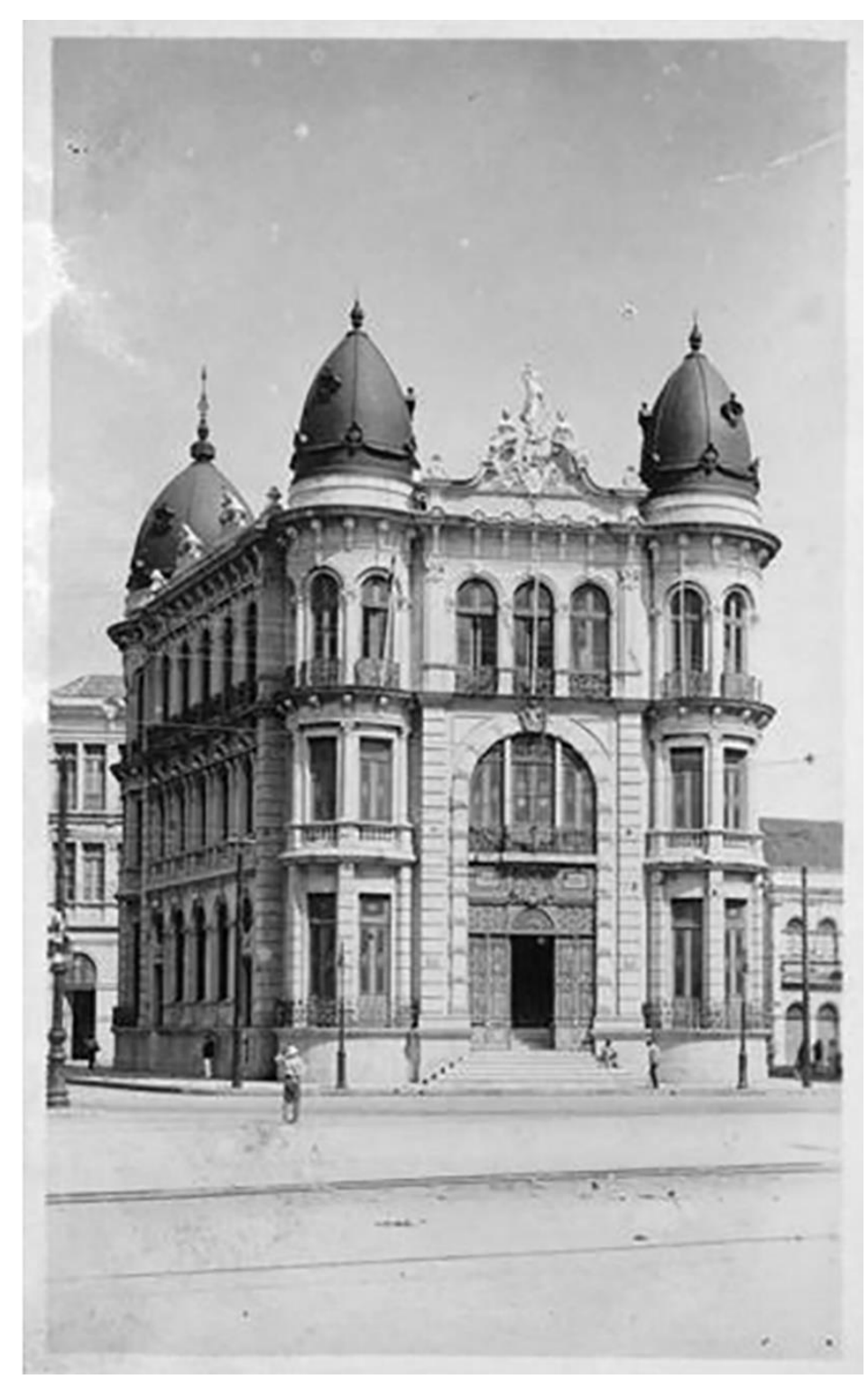

Figura 22: Conjunto escultórico no topo da Associação Comercial de Pernambuco. Fonte: Núcleo de digitalização Fundação Joaquim Nabuco.

A restauração da parte externa coube ao arquiteto Ronaldo Câmara ${ }^{18}$, que afirma ter sido encomendada uma réplica da estátua de Mercúrio para ser colocada no antigo lugar. A restituição ao local das outras duas peças dependia, se encontradas, da anuência do IPHAN, que já não havia aprovado a instalação de um medalhão, presente na versão original do edifício. Após a restauração, somente a figura de Mercúrio voltou ao topo do prédio (Figuras 23 e 24-detalhe).

18 Jornal do Commercio, 30 dez 2008. Disponível em:

<http://jc.uol.com.br/jornal/2008/12/30/not_313414.php>. Acesso em 29 jan 2015.

Heródoto, Unifesp, Guarulhos, v. 4, n. 2, 2019.2 p. 206-240

DOI: $10.34024 /$ herodoto.2019.v4.10973 


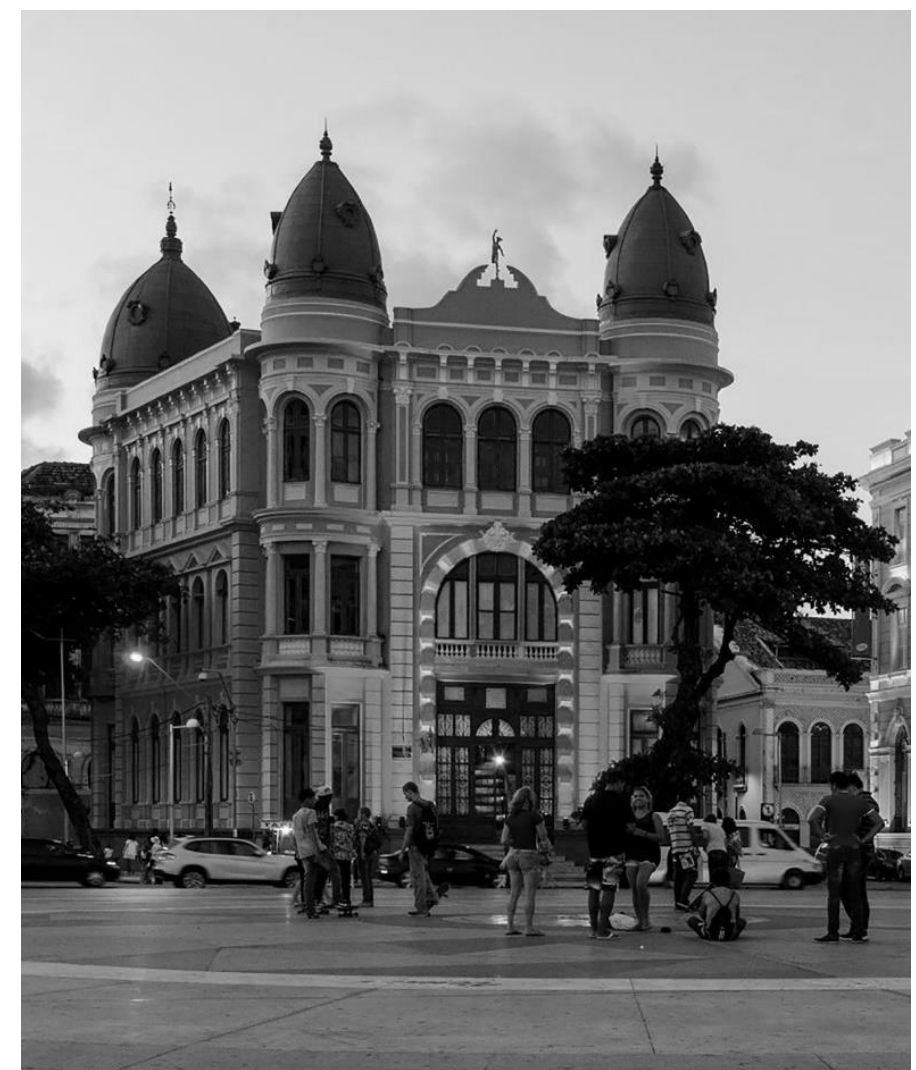

Figura 23: Situação atual do prédio da Associação Comercial de Pernambuco com apenas uma escultura no topo. Fonte: Disponível em: <http://www.skyscrapercity.com/showthread.php?t=1145917>. Acesso em out 2019.

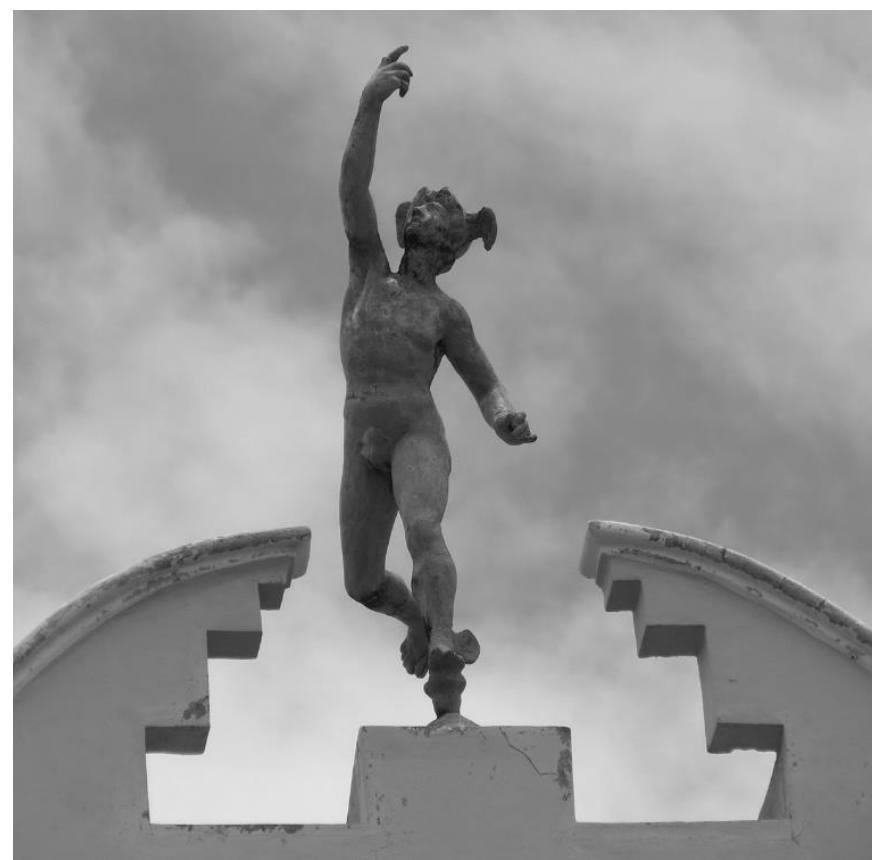

Figura 24: Imagem de Mercúrio na Associação Comercial de Pernambuco. Fonte: fotografia de Renato Pinto, 2016. 


\section{O Mercúrio de Londrina}

Identificou-se mais um Mercúrio Voador em prédio alusivo ao associativismo comercial. Desta vez, embora seja um Giambologna, é mais "moderno". Em vez de associar-se ao ecletismo, seu contexto arquitetônico é o Art Déco. Trata-se da estátua que ficava no alto do prédio de três andares da Associação Comercial de Londrina - ACL, no Paraná, concluído em 1942 (Figura 25) ${ }^{19}$.

Diferentemente dos exemplares do início do século XX, do Rio de Janeiro, Manaus e Pelotas, importados da Europa, o Mercúrio de Londrina foi produzido no Brasil. A escultura, medindo 4 metros de altura, concluída em 1941, foi encomendada no ano anterior pelo presidente da associação, David Dequech, a um artista do estado de São Paulo, Lélio Coluccini (19101983), imigrante italiano que participou do modernismo brasileiro, fazendo parte do círculo de amizade de Vitor Brecheret. O Mercúrio não era a única citação clássica que os sócios da emergente associação comercial introduziram no prédio: havia também duas estátuas da deusa Ceres, vinculada à agricultura - no caso, referência ao café, base da riqueza da cidade recém fundada por imigrantes no norte do Paraná! (CAVAZOTTI, 2017, p. 34-36).

A presença deste Mercúrio Voador reforçava o sentido de prosperidade desta cidade emergente, de crescimento rápido. Ele se impunha na paisagem urbana, como testemunha Gladys Silva Lessa, que chegou ainda criança em Londrina no ano de 1937: "Para nós, crianças numa cidade ainda pequena, a estátua era uma atração enorme. A gente nunca tinha visto aquilo, nem por fotografia. Quando chegou, ficamos fascinados. Um Deus, e ainda por cima, de asinhas. Era fascinante". A impressão de outra criança da época, Nelson Dequech, reforça a importância que a escultura possuía: "Aquilo lá foi o cartão postal da cidade por muito tempo" (CAVAZOTTI, 2017, p. 36).

Uma fotografia da época registra quando a imagem foi içada ao alto do prédio (Figura 26), em 1942, meses antes da inauguração da então ACL. Manteve-se ali por algumas décadas, acima do relógio que havia no topo da fechada. Ficou até a demolição do primeiro edifício, em 1970, dando lugar ao atual "Palácio do Comércio", de 20 andares, onde a ACIL continua até hoje, no primeiro andar.

${ }_{19}$ Na década de 1990, passou a chamar-se Associação Comercial e Industrial de Londrina - ACL. 
O Mercúrio paranaense se preservou ao longo do tempo graças ao empenho da presidência da associação. Com a participação do Brasil na Segunda Grande Guerra Mundial, a estátua de bronze foi requisitada pelo Exército para ser fundida e transformada em bala de canhão. Quando constroem a nova sede, a estátua foi transferida para a Reitoria da Universidade Estadual de Londrina, onde "participou" de inúmeras manifestações estudantis ${ }^{20}$, até ser instalada definitivamente no saguão do Palácio do Comércio, em 1990, sobre um pedestal erguido em um canteiro ajardinado (Figura 27).

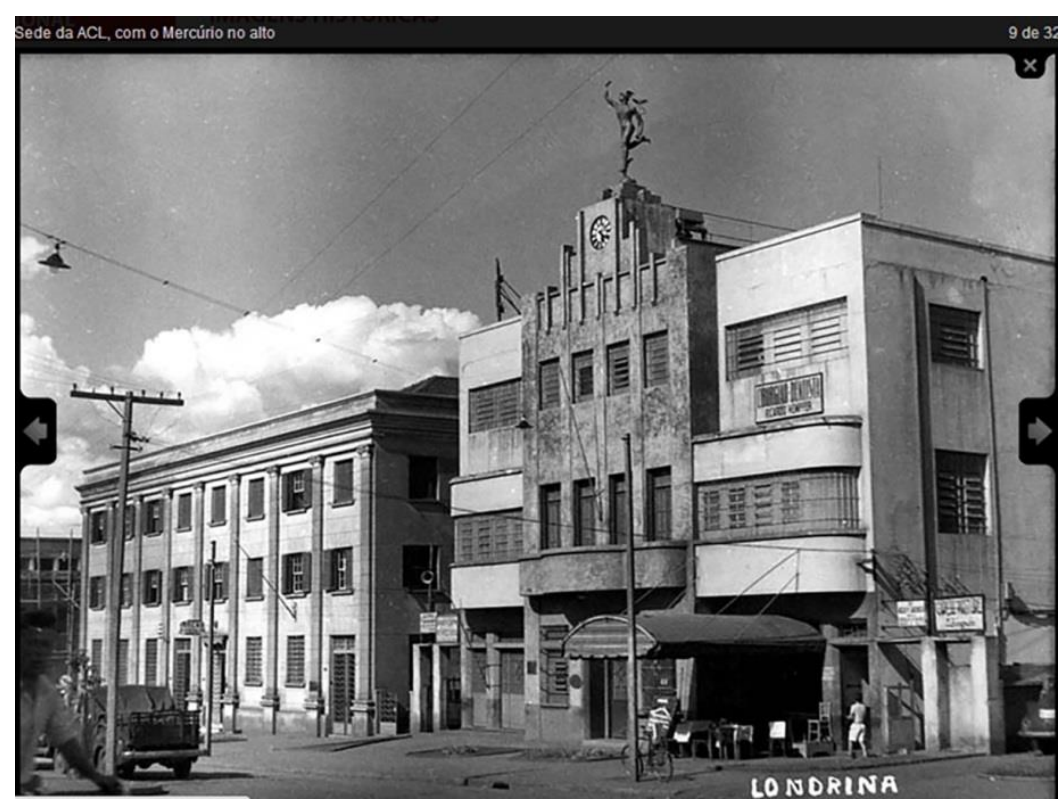

Figura 25: Prédio da Associação Comercial de Londrina, PR. Ano de 1942. Fonte: Associação Comercial e Industrial de Londrina.

${ }^{20}$ Revista da Associação Comercial e Industrial de Londrina, ano 1, nº 1, 2012, p. 25. Disponível em: $\quad<$ http://www.acil.com.br/upload/revistas/mercado-em-foco-01-julho-asetembro-2012-20120706-095701-20121207-102701.pdf>. Acesso em out 2019. 


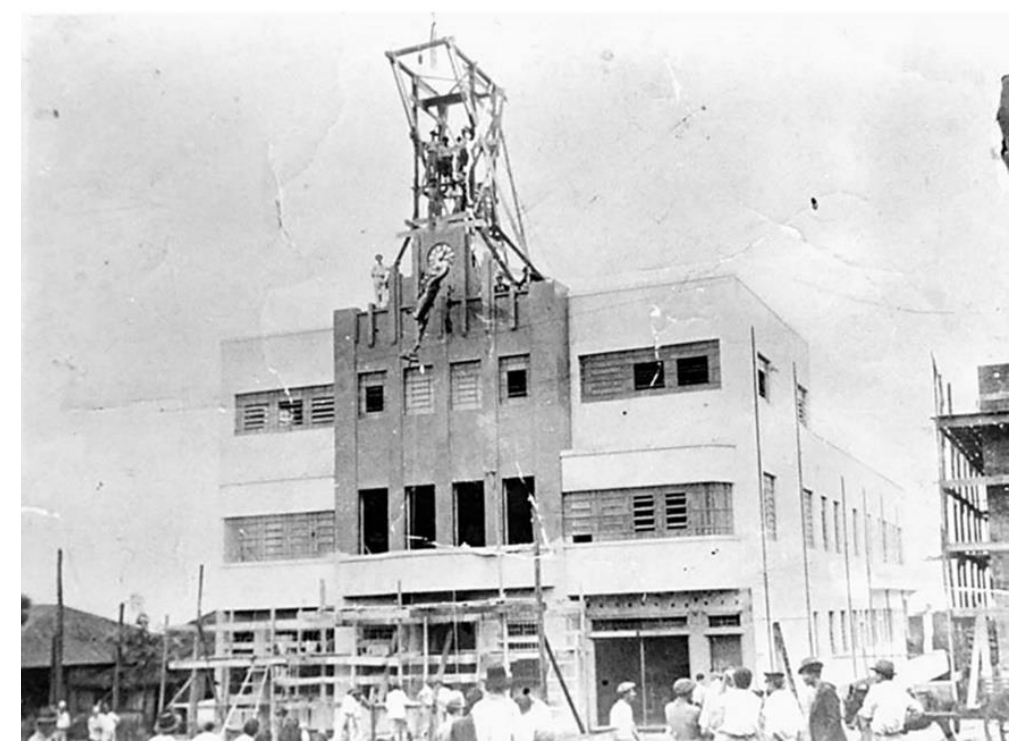

Figura 26: Mercúrio em Londrina, içado ao alto do prédio da Associação Comercial de Londrina. Ano de 1942. Fonte: Associação Comercial e Industrial de Londrina. 


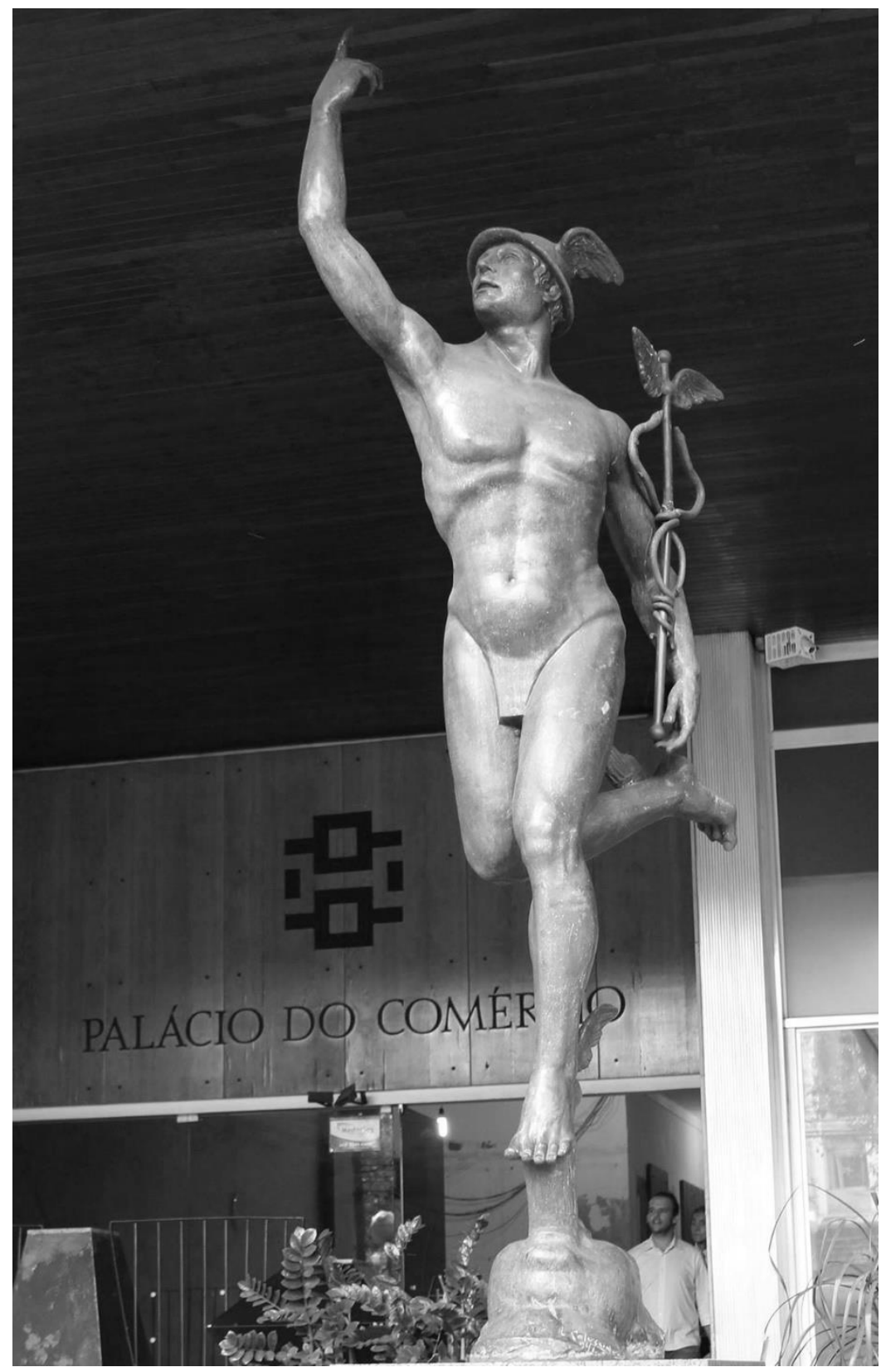

Figura 27: Escultura no saguão do edifício Palácio do Comércio, em Londrina.Fonte: Associação Comercial e Industrial de Londrina.

\section{Considerações finais}

A presença do "Mercúrio Voador" em Pelotas permeia a história local. Está inserida em um cenário em que a cidade, já urbanizada e moderna, emergia de um próspero período de desenvolvimento econômico-cultural iniciado com a indústria do charque, ainda no final do século XVIII, e consolidado pelas atividades do comércio, da pecuária e das indústrias que se desenvolveram em decorrência da acumulação de capital gerada pela 
indústria saladeiril, principalmente após encerrar o conflito farroupilha, em 1845.

Essa escultura é uma expressão do ecletismo historicista ocorrido em Pelotas, aproximadamente entre 1870 e 1930, período marcado por uma arquitetura que atrelava alegorias e elementos ornamentais neoclássicos às funções dos prédios e às idiossincrasias de seus habitantes. Era próprio do ecletismo a busca de um vínculo com algum período do passado, que em sua essência era uma busca por origens, para aí enraizar a identidade nacional. No caso de Pelotas, caracteriza-se pelas remissões ao Renascimento italiano e/ou à tradição clássica. A sociedade "moderna e civilizada", do último quartel do século XIX, espelhava-se em um ideal de Antiguidade, em que Mercúrio funcionava como emblema de civilização.

Nesse sentido, o Mercúrio de Pelotas não se constitui um fenômeno isolado. Fazia parte de um "Brasil de Mercúrios", em um contexto de cidades que viveram ciclos de prosperidade na Belle Époque, como Manaus, Recife e Rio de Janeiro. Dessa sorte, esses Mercúrios tinham um papel no imaginário social urbano. Nessa época, a Recepção do Clássico atuava na formação da identidade nacional. A Antiguidade era um parâmetro de civilização para a cultura urbana.

A presença do Mercúrio testemunha, sobretudo, um passado de uma Pelotas mergulhada em um cenário cosmopolita, reflexo da forte presença de estrangeiros e de uma mentalidade aberta resultante do industrialismo e do comércio.

Além dos Mercúrios mostrados acima, outros tantos "povoam" o topo de prédios, frontões, praças, fachadas de clubes e bancos, museus e galerias de arte do mundo inteiro, alimentando o imaginário e identidade de sociedades que encontraram na figura de Mercúrio o simbolismo dos valores coletivos que buscavam: força, poder, prosperidade, inteligência, humanidade, desenvolvimento, progresso, ou seja, civilização.

\section{Agradecimentos}

Pelo financiamento, somos gratos ao CNPq, à CAPES e à HumboldtFoundation. Pelas imagens, agradecemos o Prof. Dr. Eduardo Arriada (Universidade Federal de Pelotas), Prof. Ms. Macário Lopes de Carvalho Júnior (Universidade Estadual do Amazonas), Prof. Dr. Renato Pinto (Universidade Federal de Pernambuco), Roberto de Moura Bonini, assim como as instituições Fundação Joaquim Nabuco, Recife, Pernambuco 
(FUNDAJ), Associação Comercial e Industrial de Londrina, Paraná (ACIL), Bibliotheca Pública Pelotense, Laboratório de Acervo Digital Universidade Católica de Pelotas (LAD/UCPel), Instituto Histórico Geográfico do Capão do Leão, Rio Grande do Sul (IHGCL), na pessoa de Arthur Victória Silva, o site E-MONUMENT.Net; pela edição das imagens, Gabriel Halfen Torino; pelo estímulo à publicação, Prof. Dr. Reinhard Stupperich (Heidelberg University); pela tradução, somos gratos a Márcia Chico e Cristina Schumacher.

\section{Referências bibliográficas}

ARRIADA, Eduardo; TAMBARÁ, Elomar. Uma História Editorial: Tipografias, Editoras e Livrarias em Pelotas. In: Almanaque do Bicentenário de Pelotas. Santa Maria: Gráfica Pallotti, 2014.

BRUNO, Guilherme Rodrigues. Mercado Central de Pelotas: a permanência no lugar do consumo. Dissertação (Mestrado em Memória Social e Patrimônio Cultural) Universidade Federal de Pelotas, 2010.

CAVAZOTTI, Fábio. Deus do Comércio. Revista Mercado em Foco. N 39, ano 5, Maio e Junho de 2017. Disponível em:< http://acil.com.br/uploads/revista/MercadoemFoco-39MaioeJunho2017-FINALWEB_ofpjotyvlkQy7RB.pdf>. Acesso em nov 2019.

DUARTE, Durango Martins. Manaus entre o passado e o presente. Manaus: Mídia Ponto Comm, 2009. Disponível em: $<$ http:/ / pt.slideshare.net/DurangoDuarte/livro-manaus-entre-opassado-e-o-presente-web96mb>. Acesso em out 2019.

FABRIS, Annateresa. Arquitetura eclética no Brasil: o cenário da modernização. Anais do Museu Paulista. São Paulo, Nova Série, nº 1, 1993. Disponível em:<http://www.scielo.br/pdf/anaismp/v1n1/a11v1n1>. Acesso em 20 fev 2017.

GUTIERREZ, Ester J. B. Barro e sangue: mão-de-obra, arquitetura e urbanismo em Pelotas 1777-1888. Pelotas: UFPel, 2004

KÜHL, Beatriz Mugayar. Arquitetura do Ferro e Arquitetura Ferroviária em São Paulo. Reflexões dobre sua preservação. São Paulo: Atelier editorial FAPESP, 1998. 
MAGAlHÃeS, Mário Osório. Opulência e cultura na Província de São Pedro do Rio Grande do Sul: um estudo sobre a história de Pelotas (1860-1890). Pelotas, Mundial, 1993.

MARSHALL, Francisco. Arqueologia clássica e patrimônio nacional. In: Cadernos do LEPAARQ. Textos sobre Antropologia, Arqueologia e Patrimônio. Pelotas: Editora da Universidade Federal de Pelotas, vol. 2, n. 4, p. 19-26, $2005 . \quad$ Disponível em: < http://www.periodicos.ufpel.edu.br/ojs2/index.php/lepaarq/article/vi ewFile/890/870>. Acesso em 26 jan 2017.

PANOFSKY, Erwin. Significado nas Artes Visuais. São Paulo: Perspectiva, 1991.

SANTOS, Carlos Alberto Ávila. Ecletismo na fronteira meridional do Brasil: 1870-1931. Tese (Doutorado em Arquitetura e Urbanismo - Área de Conservação e Restauro) Universidade Federal da Bahia, 2007.

SCHLEE, Andrey Rosenthal. O ecletismo na arquitetura pelotense até as décadas de 30 e 40. Dissertação (Mestrado em Arquitetura e Urbanismo). Universidade Federal do Rio Grande do Sul, 1993.

SILVA, Geraldo Gomes da. Arquitetura do Ferro no Brasil. São Paulo:Nobel, 1986. 